\title{
PAK Inactivation Impairs Social Recognition in 3xTg-AD Mice without Increasing Brain Deposition of Tau and $A \beta$
}

\author{
Dany Arsenault, $, 1,2 \star$ Alexandre Dal-Pan, ${ }^{2 \star}$ Cyntia Tremblay, ${ }^{2}$ David A. Bennett, ${ }^{3}$ Matthieu J. Guitton, ${ }^{4,5}$ \\ Yves De Koninck, ${ }^{4,5}$ Susumu Tonegawa, ${ }^{6}$ and Frédéric Calon ${ }^{1,2}$ \\ ${ }^{1}$ Faculté de pharmacie, Université Laval, Quebec City, G1V 0A6, Quebec, Canada, ${ }^{2}$ Centre Hospitalier de l'Université Laval, Research Center, Quebec City, \\ Quebec, G1V 2L9, Canada, ${ }^{3}$ Rush Alzheimer's Disease Center, Department of Neurological Sciences, Rush University Medical Center, Chicago, Illinois \\ 60612, ${ }^{4}$ Faculté de médecine, Université Laval, Quebec City, Quebec, G1V 0A6, Canada, ${ }^{5}$ Institut Universitaire en Santé Mentale de Québec, Quebec City, \\ Quebec, G1J 2G3, Canada, and ${ }^{6}$ Massachusetts Institute of Technology, Cambridge, Massachusetts 02139
}

Defects in p21-activated kinase (PAK) are suspected to play a role in cognitive symptoms of Alzheimer's disease (AD). Dysfunction in PAK leads to cofilin activation, drebrin displacement from its actin-binding site, actin depolymerization/severing, and, ultimately, defects in spine dynamics and cognitive impairment in mice. To determine the role of PAK in AD, we first quantified PAK by immunoblotting in homogenates from the parietal neocortex of subjects with a clinical diagnosis of no cognitive impairment $(n=12)$, mild cognitive impairment $(n=12)$, or $\mathrm{AD}(n=12)$. A loss of total PAK, detected in the cortex of AD patients $(-39 \%$ versus controls), was correlated with cognitive impairment $\left(r^{2}=0.148, p=0.027\right)$ and deposition of total and phosphorylated tau $\left(r^{2}=0.235\right.$ and $r^{2}=0.206$, respectively), but not with A $\beta 42\left(r^{2}=0.056\right)$. Accordingly, we found a decrease of total PAK in the cortex of 12-and 20-month-old 3xTg-AD mice, an animal model of AD-like $\mathrm{A} \beta$ and tau neuropathologies. To determine whether PAK dysfunction aggravates AD phenotype, $3 \mathrm{xTg}$-AD mice were crossed with dominant-negative PAK mice. PAK inactivation led to obliteration of social recognition in old 3xTg-AD mice, which was associated with a decrease in cortical drebrin $(-25 \%)$, but without enhancement of A $\beta /$ tau pathology or any clear electrophysiological signature. Overall, our data suggest that PAK decrease is a consequence of AD neuropathology and that therapeutic activation of PAK may exert symptomatic benefits on high brain function.

\section{Introduction}

Synaptic dysfunction occurs early in Alzheimer's disease (AD) and is thought to underlie cognitive impairment before widespread neuronal loss (Selkoe, 2001; Calon et al., 2004; Moolman et al., 2004; Masliah et al., 2006; Scheff and Price, 2006; Rodríguez and Verkhratsky, 2011; Selkoe, 2011; Huang and Mucke, 2012). It has been postulated that $\mathrm{p} 21$-activated kinase (PAK)-related molecular pathways are essential to synaptic health and therefore are potential therapeutic targets in $\mathrm{AD}$ (Zhao et al., 2006; Ma et al., 2008; Huang et al., 2011; Dubos et al., 2012). PAKs are serine/ threonine protein kinases (Bokoch, 2003; Boda et al., 2006; Kreis and Barnier, 2009; Huang et al., 2011) that play critical roles in regulating the formation and maintenance of postsynaptic dendritic spines through actin remodeling (Rousseau et al., 2003; Salminen et al., 2008; Kreis and Barnier, 2009; Szczepanowska, 2009). PAK inhibition causes cognitive impairment in

\footnotetext{
Received April 8, 2013; revised; ; accepted May 13, 2013.

Author contributions: F.C. designed research; D.A., A.D.-P., and C.T. performed research; D.A.B. and S.T. contributed unpublished reagents/analytic tools; D.A., A.D.-P., D.A.B., M.G., Y.D.K., and F.C. analyzed data; D.A., A.D.-P., and F.C. wrote the paper.

We thank Atsou Dzini Memelio for technical assistance and Dr. Zhong-Wei Zhang for instrumentation support. The authors declare no competing financial interests.

${ }^{*}$ D.A. and A.D.-P. contributed equally to this work.

Correspondence should be addressed to Frédéric Calon, PhD, Centre de recherche du CHU de Québec, Neurosciences Axis, Québec, G1V 4G2, Canada. E-mail: Frederic.Calon@crchul.ulaval.ca.

DOI:10.1523/JNEUROSCI.1501-13.2013

Copyright $\odot 2013$ the authors $\quad 0270-6474 / 13 / 3310729-12 \$ 15.00 / 0$
}

dominant-negative PAK-transgenic mice (dnPAK; Hayashi et al., 2004), in adult mice after intracerebral infusion of inhibitors (Zhao et al., 2006), and in double PAK1/3 knock-out mice (Huang et al., 2011).

Decreases in cytosolic PAK concentrations have been found in the cortex and hippocampus of persons who died with advanced AD (Heredia et al., 2006; Zhao et al., 2006; Ma et al., 2008; Nguyen et al., 2008). Moreover, immunohistochemical studies showed a cofilin-positive cluster labeling of active PAK in AD patients (Zhao et al., 2006). PAK dysfunction was proposed to lead to cofilin activation, drebrin displacement from its actinbinding site, actin depolymerization/severing, and, ultimately, defects in spine dynamics (Minamide et al., 2000; Bokoch, 2003; Zhao et al., 2006; Kreis and Barnier, 2009; Dubos et al., 2012). This pathogenic hypothesis is supported by data in cultured hippocampal cells and in rodents, in which intracerebral injections of PAK inhibitors induced drebrin translocation from membrane to cytosol (Zhao et al., 2006; Ma et al., 2008). Accordingly, reduction of PAK catalytic activity in vivo induces a decrease in the spine density within cortical neurons and shifts the overall spine distribution toward spines of shorter length with larger postsynaptic densities (Hayashi et al., 2004; Hayashi et al., 2007). Converging data indicate that PAK activation is essential for the maturation and maintenance of dendritic spines and thus for the proper functioning of the brain. PAK activation therefore represents a promising therapeutic target in $\mathrm{AD}$ and other dementias. 
A

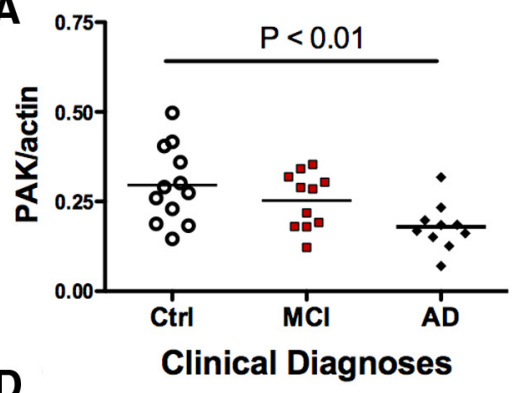

D

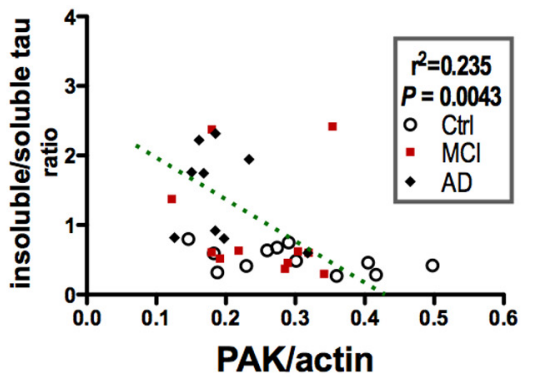

G

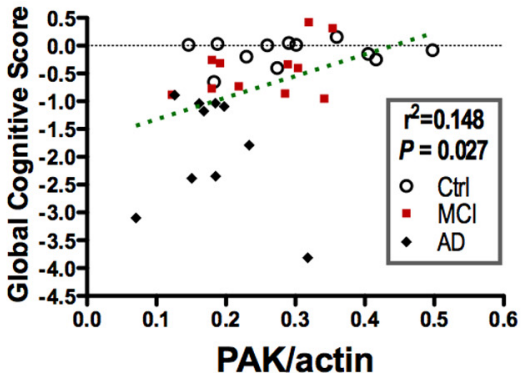

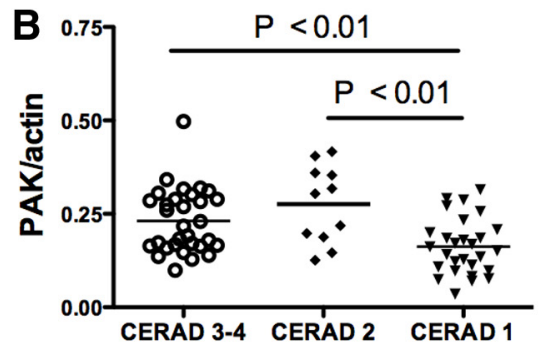

C
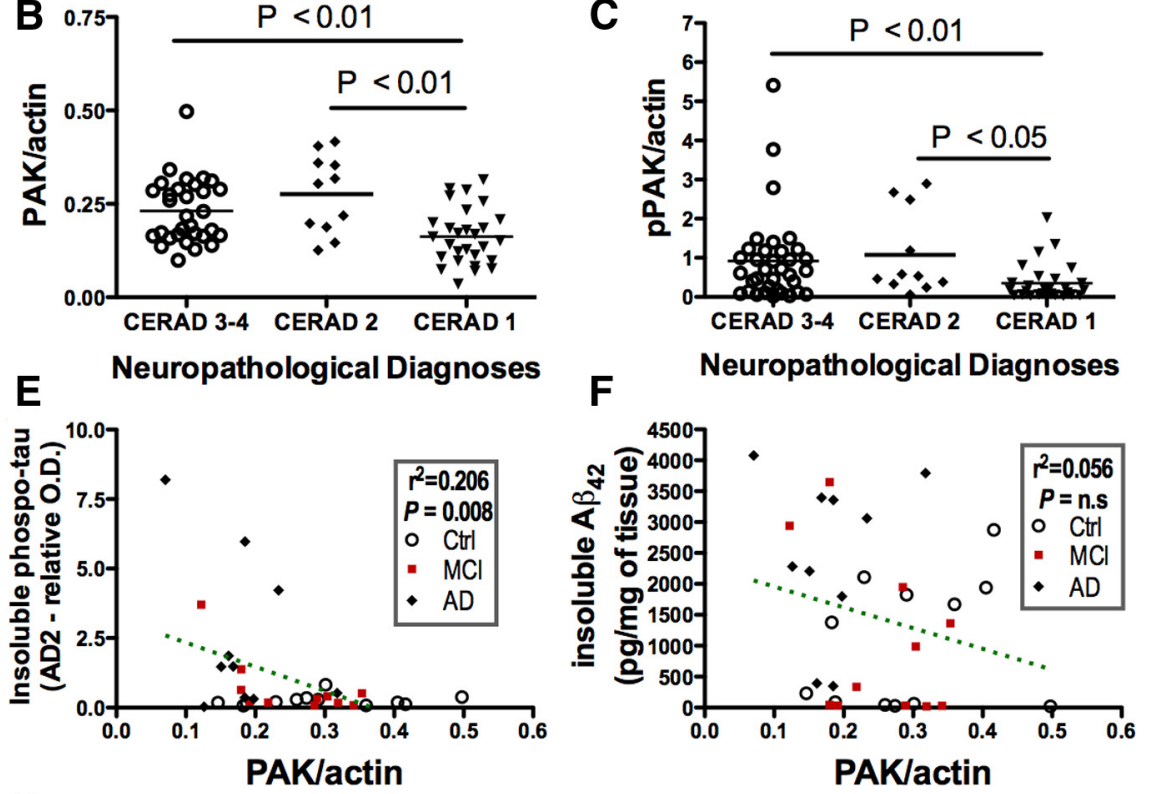

H

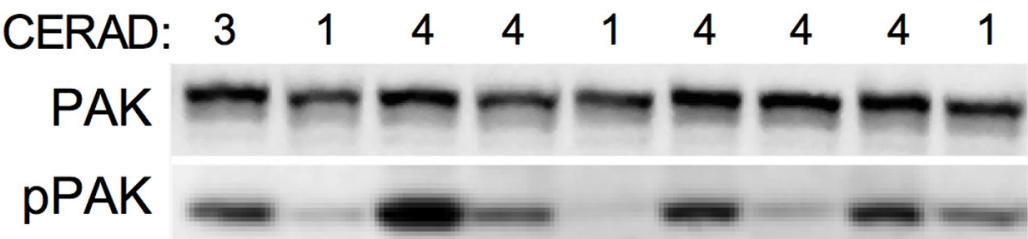

Actin

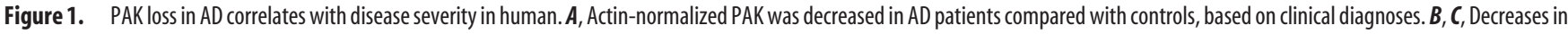
actin-normalized PAK (B) and PPAK (C) were observed in individuals with definitive neuropathological diagnosis of AD (CERAD 1) compared with those with a "probable" diagnosis of AD (CERAD 2) or low AD probability (possible or none, (ERAD 3 or 4). $D-G$, Linear regression analyses showed that actin-normalized PAK (in the soluble fraction) was correlated negatively with the ratio of insoluble tau fraction on the soluble tau fraction $(\boldsymbol{D})$ and insoluble $\mathrm{PHF}_{\text {tau }}(\boldsymbol{E})$, but not with the accumulation of insoluble $A \beta 42(\boldsymbol{F})$, but was positively associated with global antemortem cognitive score $(\boldsymbol{G})$. $\boldsymbol{H}$, Examples of Western blot results obtained for PAK and pPAK in control, MCI, and AD patients. All samples were run simultaneously on the same SDS-PAGE gels. Statistical analyses: one-way ANOVA/Dunnett's multiple-comparison test $(\boldsymbol{A})$, Kruskal-Wallis/Dunn's multiple-comparison test $(\boldsymbol{B}, \boldsymbol{C})$, and linear regression $(\boldsymbol{D}-\boldsymbol{G})$.

To determine the significance of a decrease of PAK activity in AD pathophysiology, we: (1) investigated the relationship of PAK, cognitive deficits, and $A \beta /$ tau neuropathologies in subjects with no cognitive deficits, mild cognitive impairment, or AD; (2) characterized age-related PAK alterations in an animal model of $\mathrm{AD}$, the $3 \mathrm{xTg}$ - $\mathrm{AD}$ mouse; (3) investigated whether PAK inactivation potentiates an $\mathrm{AD}$-relevant behavioral and molecular phenotype in vivo by crossing $3 \mathrm{xTg}$ - $\mathrm{AD}$ mice with dnPAK mice (Hayashi et al., 2004); and (4) sought to determine whether the electrophysiological parameters known to be impaired in $\mathrm{AD}$ mice models (Harris et al., 2011; Verret et al., 2012), and more specifically in 3xTg-AD mice (Arsenault et al., 2011), were corrected or aggravated by PAK defects.

\section{Materials and Methods}

\section{Patients and handling of brain tissue}

Samples from the parietal cortex of 36 individuals from the Religious Orders Study were divided into three groups based on clinical diagnoses: 12 with mild cognitive impairment (MCI), 12 with $\mathrm{AD}$, and 12 with no cognitive impairment, as described previously (Bennett et al., 2002; Bennett, 2006; Tremblay et al., 2007; Julien et al., 2009). MCI defines a group of otherwise healthy elderly subjects with a markedly elevated risk of developing $\mathrm{AD}$ and a more rapid rate of decline in cognitive functions (Boyle et al., 2006). In addition, MCI is considered as a possible early clinical manifestation of AD (Bennett et al., 2005). Each participant underwent a uniform structured baseline clinical evaluation, details of which have been described previously (Bennett et al., 2002; Bennett et al., 2005; Bennett, 2006). Briefly, the composite index of global cognition combined 19 separate tests including measures of episodic, semantic, and working memory, as well as perceptual speed and visuospatial ability (Wilson et al., 2002). At death, each case was assigned a Braak score based on neurofibrillary tau pathology, a senile plaque score based on modified Consortium to Establish a Registry for Alzheimer's Disease (CERAD) criteria, and a diagnosis based on the National Institute on Aging-Reagan criteria by a neuropathologist shielded to all clinical data (Bennett et al., 2005). To further investigate the link between PAK and the CERADbased neuropathological diagnosis, we added parietal cortex samples of $19 \mathrm{AD}$ patients and 22 controls obtained from the Douglas Hospital Research Centre (Quebec) brain bank, which have been fully described in previous studies (Fig. 1C; Julien et al., 2008; Julien et al., 2009). In Julien et al. (2009), the neuropathological diagnosis of AD was made only at neuropathological examination and was based on CERAD scores. In all subjects, cerebellar $\mathrm{pH}$ was measured to assess the degree of preservation of the tissue (Kingsbury et al., 1995; Calon et al., 2003). Concentrations of $\mathrm{A} \beta$ and tau were assessed using ELISA and Western immunoblotting, respectively, in the inferior parietal cortex of all volunteers, as described previously (Tremblay et al., 2007; Julien et al., 2008). Relevant information regarding all subjects involved in this study is available in a previous publication (Julien et al., 2009). 


\section{Transgenic models}

All procedures were approved by the Laval University animal ethics committee (protocol 10-037) and were performed according to the guidelines of the Canadian Council on Animal Care. The 3xTg-AD mouse model has been described previously (Oddo et al., 2003a; Oddo et al., 2003b; Mastrangelo and Bowers, 2008; Phivilay et al., 2009; Julien et al., 2010; Arsenault et al., 2011). In brief, 3xTg-AD mice express the mutated gene $\mathrm{PS}_{\mathrm{M} 146 \mathrm{~V}}$ (knock-in) and mutated human genes $\mathrm{APP}_{\mathrm{Swe}}$ and $\mathrm{tau}_{\mathrm{P} 301 \mathrm{~L}}$ in the same locus, both under the control of the mouse Thy1.2 regulatory element (Oddo et al., 2003a; Oddo et al., 2003b; Mastrangelo and Bowers, 2008). These transgenic mice develop an age-related progressive neuropathological phenotype that includes both plaques and tangles distributed along a regional pattern similar to $\mathrm{AD}$ (Oddo et al., 2003a; Ackl et al., 2005; Mastrangelo and Bowers, 2008; Martinez-Coria et al., 2010). Finally, this AD mouse model presents behavioral and cognitive changes that are correlated with the development of the $\mathrm{A} \beta$ and tau pathology (Sterniczuk et al., 2010). Nontransgenic (NonTg) mice were derived from the original mouse line and were of the same genetic background.

PAK inactivation in $3 \times \mathrm{Tg}$-AD mice was generated by crossing homozygous $3 \mathrm{xTg}-\mathrm{AD}$ mice with heterozygous mice expressing the dnPAK transgene, which codes for a PAK autoinhibitory domain binding to PAK catalytic site (Hayashi et al., 2004). Expression of this autoinhibitory domain therefore decreases PAK1/2/3 kinase activity (Zhao et al., 1998; Zenke et al., 1999; Hayashi et al., 2004). dnPAK transgene expression is under control of the CaMKII promoter, leading to an expression restricted to the postnatal forebrain (Hayashi et al., 2004). In addition, dnPAK was marked with a $m y c$-tag sequence fused in-frame to the $\mathrm{N}$ terminus of the autoinhibitory domain-PAK sequence (Hayashi et al., 2004). This crossing produced heterozygous $3 \times \mathrm{Tg}$-AD mice express-

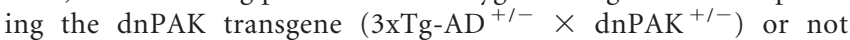
$\left(3 \times \mathrm{Tg}^{-\mathrm{AD}^{+/-}} \times \mathrm{dnPAK}^{-1-}\right)$. Animals were killed at either 12 or 20 months and the parietotemporal cortex was used to quantify proteins and neuropathological markers. Both females and males were used in this study.

\section{Preparation of tissue samples}

Tissue extracts (50 mg of mouse tissue or $100 \mathrm{mg}$ of human tissue) were homogenized in 4 (human) or 8 (mouse) volumes of TBS containing a complete protease inhibitor mixture (Roche), $10 \mu \mathrm{g} / \mathrm{ml}$ pepstatin $\mathrm{A}, 0.1$ mM EDTA, and phosphatase inhibitors (1 mm each of sodium vanadate and sodium pyrophosphate, $50 \mathrm{~mm}$ sodium fluoride). The frozen samples were sonicated briefly $(3 \times 10 \mathrm{~s})$ and centrifuged at $100,000 \times \mathrm{g}$ for $20 \mathrm{~min}$ at $+4^{\circ} \mathrm{C}$ to generate a TBS-soluble fraction (soluble or cytosolic fraction). The TBS-insoluble pellets were sonicated in 8 (mice) or 4 (human) volumes of lysis buffer ( $150 \mathrm{~mm} \mathrm{NaCl}, 10 \mathrm{~mm} \mathrm{NaH}_{2} \mathrm{PO}_{4}, 1 \%$ Triton $\mathrm{X}-100,0.5 \%$ SDS, and $0.5 \%$ deoxycholate) containing the same protease and phosphatase inhibitor mixture. The resulting homogenate was centrifuged at $100,000 \times \mathrm{g}$ for $20 \mathrm{~min}$ at $+4^{\circ} \mathrm{C}$ to produce a lysis buffersoluble fraction (detergent-soluble or membrane fraction). The pellet (detergent-insoluble fraction) was homogenized in $175 \mu$ l of $90 \%$ formic acid followed by sonication $(3 \times 10 \mathrm{~s})$. The mouse supernatant was divided in two portions and dried out with a SpeedVac (Thermo Savant). One portion was solubilized in guanidine- $\mathrm{HCl}(5 \mathrm{M}$ guanidine in Tris$\mathrm{HCl} 0.05 \mathrm{M}$ ) and then sonicated shortly for solubilization to be used for ELISA; the other portion was solubilized in Laemmli's buffer for Western immunoblotting. For the human tissue, the resultant suspension was centrifuged $\left(13,000 \times \mathrm{g}\right.$ at $+4^{\circ} \mathrm{C}$ for $\left.20 \mathrm{~min}\right)$ and $20 \mu \mathrm{l}$ of each supernatant was neutralized with 1:30 dilution of Tris-base $1 \mathrm{M}, \mathrm{pH} 10$, to be used for ELISA (see below). The rest of the supernatants were dried out with a SpeedVac, solubilized in Laemmli's buffer, and processed for Western immunoblotting (insoluble fraction; see below).

\section{ELISA}

$\mathrm{A} \beta 40$ and $\mathrm{A} \beta 42$ from human brain samples were measured with the hAmyloid $\beta 40 / \beta 42$ ELISA HS kits (The Genetics Company), as described previously (Tremblay et al., 2007). Amyloid $\beta 40 / \beta 42$ ELISA kits (Biosource) were used to analyze mouse tissue. Both ELISAs were performed in the soluble and insoluble protein fraction according to the manufacturers' recommendations and the plates were read at $450 \mathrm{~nm}$ using a Synergy HT multidetection microplate reader (Biotek).

\section{Western immunoblotting}

Protein concentration was determined using bicinchoninic acid assays (Pierce). For Western immunoblotting, equal amounts of protein per sample $(15 \mu \mathrm{g})$ were added to Laemmli's loading buffer, heated to $+95^{\circ} \mathrm{C}$ for $5 \mathrm{~min}$ before loading, and subjected to SDS-PAGE (8\%). Proteins were electroblotted onto PVDF membranes (Millipore) before blocking in 5\% nonfat dry milk and 1\% BSA in PBS-Tween 20 for $1 \mathrm{~h}$. Membranes were immunoblotted with appropriate primary and secondary antibodies followed by chemiluminescence reagents (Lumiglo Reserve; KPL). Band intensities were quantified using a Kodak Image Station $4000 \mathrm{MM}$ Digital Imaging System (Molecular Imaging Software version 4.0.5f7; Carestream Health). The following antibodies were used in this study: anti-actin (ABM), anti-cofilin (Cell Signaling Technology), anti-drebrin (MBL International), anti-synaptophysin clone SVP-38 (Millipore), anti-PAK1 (Invitrogen), anti-PAK3 and anti-total PAK (Cell Signaling Technology), anti-phospho-PAK1/2/3 (phosphorylated at serine 141; Invitrogen), anti-total tau clone tau13 (Covance), and anti-phospho-tau clones CP13 (phosphorylated at serine 202/threonine 205; gift from Dr Peter Davies, Albert Einstein College of Medicine, New York), and AD2 ( phosphorylated at serines 396 and 404; Bio-Rad).

\section{Immunohistofluorescence staining}

Hemi-brains were postfixed with $4 \%$ PFA $\left(4^{\circ} \mathrm{C}\right.$ overnight), cryoprotected with $20 \%$ sucrose-PBS, snap frozen at $-80^{\circ} \mathrm{C}$, and microtome sectioned into coronal $(25 \mu \mathrm{m})$ sections. Washes in $0.1 \mathrm{M}$ PBS, pH 7.4, were performed between each step of the immunohistofluorescence protocols. Free-floating brain sections from $3 \times \mathrm{Tg}$-AD mice with or without dnPAK transgene were blocked for $1 \mathrm{~h}$ in a PBS solution containing 5\% horse serum (Invitrogen) and $0.4 \%$ Triton X-100. Sections were then incubated overnight at $4^{\circ} \mathrm{C}$ with primary antibodies in the blocking solution: rabbit anti-Myc-Tag (1:100; Cell Signaling Technology), rabbit antipPAKs141 (1:100; Invitrogen Corporation), and mouse anti-neuronal nuclei (NeuN, 1:1000; Millipore). After incubation with primary antibodies, slices were exposed to AF-conjugated donkey anti-rabbit and anti-mouse secondary antibodies (1:1000; Invitrogen). Finally, slices were counterstained with DAPI (Invitrogen), mounted on SuperFrost Plus slides (Thermo Fisher Scientific), treated with $0.5 \%$ Sudan black (in 70\% methanol) for $5 \mathrm{~min}$, and placed under coverslips with Mowiol mounting medium. Sections were transferred onto SuperFrost Plus slides and placed under coverslips with Mowiol mounting medium.

\section{Slice preparation for electrophysiology recordings}

Brain slices were prepared as described previously (Zhang and Arsenault, 2005; Arsenault and Zhang, 2006). Briefly, mice were deeply anesthetized with ketamine (100 mg/kg, i.p.) and xylazine ( $10 \mathrm{mg} / \mathrm{kg}$, i.p. $)$ and decapitated. The brain was removed quickly $(<60 \mathrm{~s})$ and placed in an ice-cold solution containing the following (in $\mathrm{mm}$ ): 210 sucrose, $3.0 \mathrm{KCl}, 1.0$ $\mathrm{CaCl}_{2}, 3.0 \mathrm{MgSO}_{4}, 1.0 \mathrm{NaH}_{2} \mathrm{PO}_{4}, 26 \mathrm{NaHCO}_{3}$, and 10 glucose saturated with $95 \% \mathrm{O}_{2}, 5 \% \mathrm{CO}_{2}$. Horizontal slices of $300 \mu \mathrm{m}$ were cut from inferior to superior brain with a vibrating tissue slicer (VT 1000s; Leica) and kept at room temperature in ACSF containing the following (in mM): 124 $\mathrm{NaCl}, 3.0 \mathrm{KCl}, 1.5 \mathrm{CaCl}_{2}, 1.3 \mathrm{MgCl}_{2}, 1.0 \mathrm{NaH}_{2} \mathrm{PO}_{4}, 26 \mathrm{NaHCO}_{3}$, and 20 glucose saturated with $95 \% \mathrm{O}_{2} / 5 \% \mathrm{CO}_{2}$. Slices were allowed to recover for at least $1 \mathrm{~h}$ before recording $(n=9-10)$.

\section{Patch-clamp recording}

For recording, a slice was transferred to a submerge-type chamber and continuously exposed to ACSF heated to $30-32^{\circ} \mathrm{C}$ saturated with $95 \%$ $\mathrm{O}_{2} / 5 \% \mathrm{CO}_{2}$ and flowing at a rate of $2.0 \pm 0.2 \mathrm{ml} / \mathrm{min}$. The slices were viewed first with a $4 \times$ objective and the deep layer of the entorhinal cortex was located beside the hippocampus. For most animals, two to three slices were recorded per hemisphere. Large deep layer neurons in the entorhinal cortex were then viewed under near-infrared illumination with a $40 \times$ water-immersion objective (Fluor, $40 \times, 0.80 \mathrm{~W}$; Nikon) and a charge-coupled device camera (IR-1000; Dage MTI).

Patch pipettes were pulled from thick-walled borosilicate glass (1.5/ $0.84 \mathrm{~mm}$; WPI) on a horizontal puller (P-97; Sutter Instruments). The pipette solution contained the following (in $\mathrm{mm}$ ): $100 \mathrm{KMeSO}_{4}, 15 \mathrm{KCl}$, 4 ATP-Mg, 10 creatine phosphate, 10 HEPES, 0.5 EGTA, pH 7.2, adjusted with $\mathrm{KOH}, 275-280 \mathrm{mOsm}$. Electrodes had resistances between 4 
and $6 \mathrm{M} \Omega$. The seal resistance was $>2 \mathrm{G} \Omega$. Whole-cell recordings were made at the soma with a Multiclamp 700A amplifier (Molecular Devices). The access resistance, usually between 10 and $30 \mathrm{M} \Omega$, was monitored throughout each experiment and only recordings with stable access were used. Experiments were conducted using the Axograph 4.9 program (Molecular Devices) or pClamp 9.2 (Molecular Devices). Data were digitized at 8 or $16 \mathrm{kHz}$ and were either not filtered or filtered at $1 \mathrm{kHz}$, depending on the recording protocol.

\section{Data analysis for electrophysiology experiments}

This study included two sets of electrophysiological experiments. The first investigated association between PAK and selected physiologic parameters (passive properties and spontaneous EPSC) known to change in 3xTg-AD mice (Arsenault et al., 2011). This investigation was performed in homozygous mice and the mean of three to five recorded neurons was used to compare with molecular data. The second set of experiments were performed to determine physiologic parameters modulated by PAK activity. These experiments were conducted in heterozygous mice and comparison was performed for each neuron.

Electrophysiological recordings were analyzed with Clampfit 9.2 (Molecular Devices). Passive properties (input resistance, cell capacitance $[C C]$, resting potential) were studied in current-clamp mode given the stronger accuracy for this recording configuration than voltage-clamp mode (Golowasch et al., 2009). The input resistance was estimated from the slope of the graph of voltage variation versus hyperpolarized current injection using the equation $V=I R^{\star} I$, where $I R$ is input resistance, $V$ is voltage variation, and $I$ is the injected current. The injected current duration was $400 \mathrm{~ms}$ and current intensities were 50,100,150, and $200 \mathrm{pA}$. $C C$ was estimated from the linear slope of the plot of $I^{\star} T=C C^{\star} V$ (i.e., for a first-order resistance-capacitance circuit), where $T$ is the time constant of voltage variation measured by fitting a single exponential function for a voltage decay over time, $V=V_{\infty}\left(1-e-{ }^{T /\left(I R^{*} C C\right)}\right)$, and $V_{\infty}$ is the asymptote, so that $T=R C$ (i.e., $V=0.632 V_{\infty}$ ) using a graphical method. $C C$ corresponds to the linear slope of the graph displaying the relationship between $I^{*} T$ versus $V$. sEPSCs were quantified in voltageclamp mode and neurons were held at $-60 \mathrm{mV}$ (near the reversal potential for GABAAR-mediated currents). The sEPSCs were automatically detected using the event detection package of Clampfit 9.2. This package uses multiple preestablished templates to optimize the detection of synaptic events.

\section{Behavioral analysis}

Social recognition. This test was based on the propensity of an adult mouse to interact less with a known mouse than with an unknown mouse of the same sex and age (Kaidanovich-Beilin et al., 2011; Winslow, 2001). In this paradigm, two mice were exposed to each other for a $20 \mathrm{~min}$ period in a transparent plastic arena $(40 \mathrm{~cm} \times 22 \mathrm{~cm} \times 18 \mathrm{~cm})$ and the time that animal spent exploring its dyad partner (sniffing, following, grooming the partner, crawling over or under) was measured. Then, the same mice were reexposed $24 \mathrm{~h}$ later and the reduction of exploratory activity for the known partner was used as an indicator of social memory. Mice were tested at 20 months of age in dyads of one $3 \times \mathrm{xg}^{-\mathrm{AD}^{+/-}} \times$ $\mathrm{dnPAK}^{-1-}$ and one $3 \mathrm{xTg}-\mathrm{AD}^{+1-} \times \mathrm{dnPAK}^{+/-}$mice.

Anxiety-like behavior. Anxiety was assessed using light/dark box test, which is based on the innate aversion of rodents to brightly illuminated areas and on the spontaneous exploratory behavior of rodents in response to the mild stressors novel environment and light. The test apparatus consists of a small dark "safe" compartment and a large illuminated "aversive" compartment (Bourin and Hascoët, 2003). Animals were positioned in the dark compartment and the time spent in the illuminated compartment was measured for $10 \mathrm{~min}$. In addition, the number of alternances between each compartment was analyzed.

Vertical/motor activity. To determine whether motor impairments could affect the social and exploratory behaviors in mice, a 10 min vertical activity test was also performed in a transparent plastic arena (20 $\mathrm{cm} \times 40 \mathrm{~cm} \times 30 \mathrm{~cm}$ ) in parallel with black and white box testing.

Exploratory behavior. Exploratory behavior of mice was assessed in a squared arena $(1 \mathrm{~m} \times 1 \mathrm{~m})$ with holes in each corner. Hole board exploration is a behavioral paradigm that is used frequently in mice and re- quires no training (Crawley, 1985). The time spent in active exploration for the 4 holes was measured during a single 5 min daily session for 3 consecutive days.

\section{Statistical analysis}

Values are expressed as mean \pm SEM. Statistical comparisons between groups were performed depending on the normality of distribution and variances equivalence between groups. For analysis in human samples, in cases of equal variance and normal distribution, ANOVA followed by post hoc pairwise comparisons (e.g., Dunnett) were used when appropriate. Groups of data that failed tests for normality and equal variance were analyzed by the nonparametric Kruskal-Wallis test followed by Dunn's test. In the animal studies, statistical comparisons were performed using a two-way ANOVA for the study of two variables simultaneously. When variable interaction was detected, statistical comparisons were performed using a one-way ANOVA followed by the Tukey-Kramer post hoc test. When only two groups were compared, unpaired Student's $t$ test was performed, except for unequal variance, for which a Welch's $t$ test was used. Finally, for both human and animal studies, the coefficient of determination $\left(r^{2}\right)$ and the significance of the degree of linear relationship between various parameters were determined with a simple regression model. Statistical analyses were performed using JMP statistical analysis software (version 8.0.2).

\section{Results}

\section{Loss of PAK in AD is associated with symptoms and neuropathology}

We first quantified PAK in the TBS-soluble protein fractions from the parietal cortex of individuals clinically determined as MCI or AD and compared them with controls. We found 39\% lower PAK concentrations in subjects with a diagnosis of $\mathrm{AD}$, but no significant differences in those with MCI (Welch ANOVA: $p=0.012$, Dunnett's multiple-comparison test: $p<0.01$ for $\mathrm{AD}$ vs controls; Fig. 1A). To further link actin-normalized PAK level with the neuropathological diagnosis, we added parietal cortex samples from the Douglas Hospital cohort to the analysis. All subjects were classified according to CERAD-based neuropathology diagnosis. We detected a 30\% lower PAK concentration in individuals with a definite neuropathologic diagnosis of AD compared with individuals with a lower probability of AD (KruskalWallis: $p=0.0095$, Dunn's multiple-comparison test: $p<0.01$ for definite $\mathrm{AD}$ versus probable/possible/no $\mathrm{AD}$; Fig. $1 B)$. We also observed a significant decrease in phospho-PAK in persons with a CERAD score of 1 (definitive AD; Kruskal-Wallis: $p=$ 0.0036, Dunn's multiple-comparison test: $p<0.01$ for definite $\mathrm{AD}$ vs possible/no AD and, $p<0.05$ for definite $\mathrm{AD}$ vs "probable" $\mathrm{AD}$; Fig. $1 C$ ). Next, we sought to establish the relationship between PAK levels and other common neuropathological markers of AD. Correlative analyses showed that actin-normalized PAK was inversely correlated with the insoluble/soluble tau ratio (Fig. $1 D$ ) and the accumulation of insoluble phospho-tau (Fig. 1E). However, no relationship was detected with the levels of insoluble $\mathrm{A} \beta_{42}$ (Fig. $1 F$ ). Finally, a positive correlation was observed between postmortem cortical PAK levels and the global cognitive score measured antemortem (Fig. 1G). The strongest associations were established with episodic memory $\left(r^{2}=0.16 ; p=\right.$ $0.0212)$ and perceptual speed $\left(r^{2}=0.23 ; p=0.0047\right)$. Partial correlation analyses showed that, after adjusting for insoluble phospho-tau, the significance of the relationship between PAK and cognitive scores was lost $\left(r^{2}=0.08 ; p=0.39\right)$, whereas the correlation between phospho-tau and cognitive scores was not affected by PAK levels $\left(r^{2}=0.26 ; p=0.0018\right)$. Such data may suggest that the association between PAK and cognition is mediated by tau, which is consistent with PAK loss being a consequence of $\mathrm{AD}$ neuropathology. Overall, these data confirm that 


\section{Comparison between genotypes (normalized to each age group) $\square$ NonTg $\square$ 3xTg-AD}
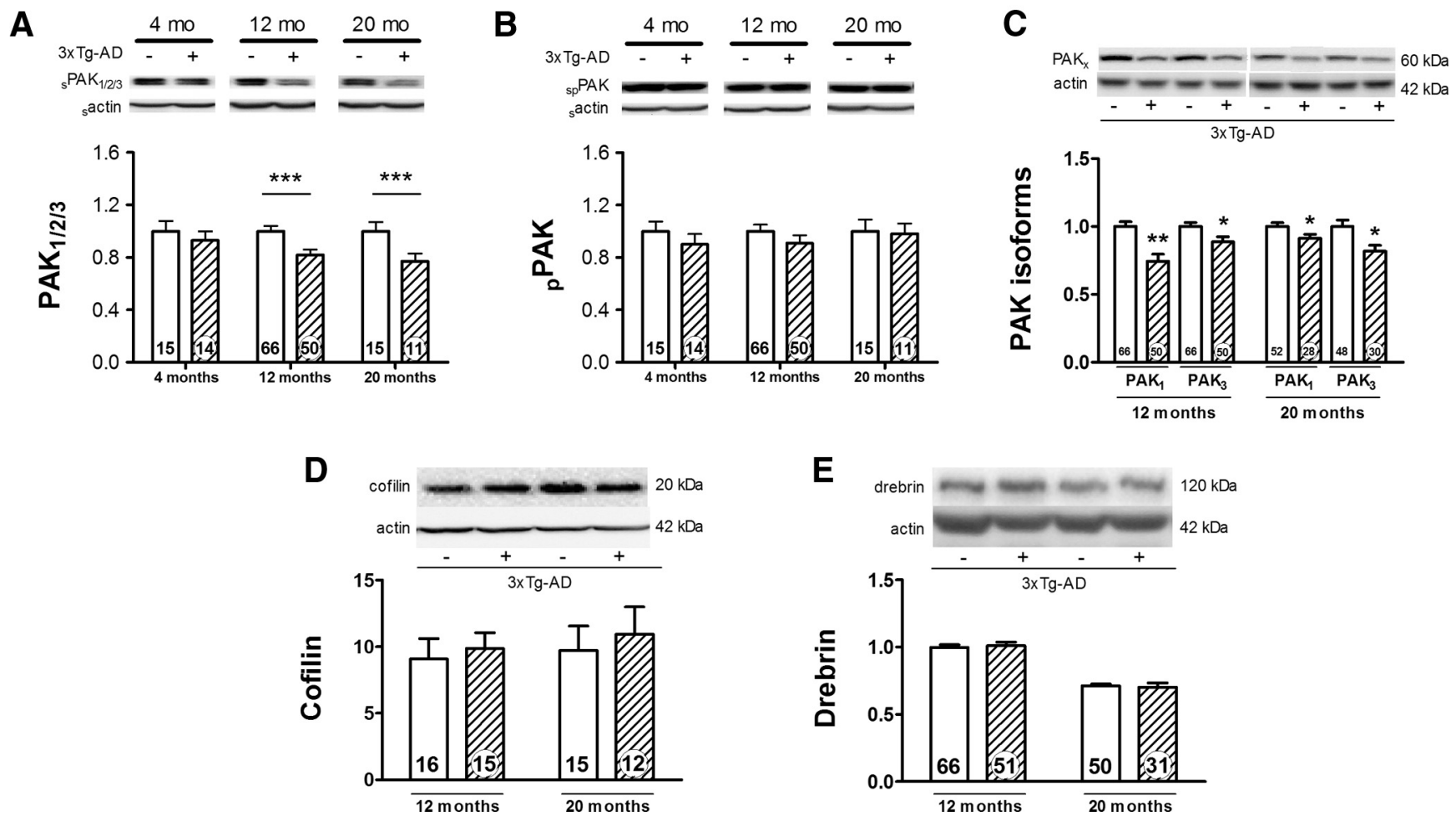

Figure 2. Characterization of PAK, membrane cofilin, and drebrin impairments in homozygous 3xTg-AD mice according to age. $A$, Soluble PAK $1 / 2 / 3$ was decreased in 12 - and 20-month-old 3xTg-AD mice compared with NonTg mice of the same age. No statistical differences were found between the two genotypes in young animals ( 4 months). $\boldsymbol{B}$, When comparing both genotypes at different ages, we observed no alteration of soluble phospho-PAK in 3xTg-AD mice at 4, 12, or 20 months. C, Loss of soluble PAK 1/2/3 $_{3}$ was observed in both isoforms 1 and 3 at all ages. Despite an age effect for drebrin level, we did not found any change of membrane cofilin $(\boldsymbol{D})$ or drebrin $(\boldsymbol{E})$ levels in 3xTg-AD compared with NonTg mice. Values are expressed as mean \pm SEM. Statistical comparisons were performed using a one-way ANOVA followed by a Tukey-Kramer post hoc test (age comparison, $\boldsymbol{A}-\boldsymbol{C}$ ) and an unpaired $t$ test $(\boldsymbol{D}, \boldsymbol{E}) .{ }^{*} p<0.5,{ }^{* *} p<0.01,{ }^{* * *} p<0.001$.

the clinical and neuropathological progression of $\mathrm{AD}$ is associated with a loss of PAK.

\section{Decrease of PAK is replicated in the 3xTg-AD mouse}

To further probe whether brain expression of tau and $\mathrm{A} \beta$ neuropathologies can cause a reduction in PAK in vivo, we quantified PAK levels in the parietotemporal cortex from the $3 x T g-A D$ mouse model at different ages (Fig. 2). We found a decrease in cortical concentrations of total PAK in 12- and 20-month-old $3 \times$ Tg-AD mice compared with NonTg controls, but not at 4 months of age, which is consistent with an age-related progressive loss of PAK (Fig. 2A). In contrast, the concentration of phospho-PAK remained unchanged (Fig. $2 B$ ). In addition, the levels of the two main cerebral isoforms of PAK, PAK1 and PAK3, were both decreased in the parietotemporal cortex of 12-monthold $(-26 \%, p<0.01$, and $-9 \%, p<0.05$, respectively) and 20 -month-old $(-11 \%$ and $-18 \%$, respectively, $p<0.05$ for both) $3 \mathrm{xTg}-\mathrm{AD}$ mice (Fig. $2 C$ ). These results indicate that the $3 \times T$ T-AD mouse replicates the decrease in PAK observed in AD patients.

Based on previously described cellular pathways, inactivation of PAK should lead to downstream cofilin activation and removal of the spine actin-regulatory protein drebrin from the membrane compartment (Zhao et al., 2006). However, despite an ageinduced decrease of drebrin levels, the concentration of cofilin and drebrin in the detergent-soluble membrane fraction remained unaltered in 3xTg-AD mice compared with NonTg mice
(Fig. 2D,E, respectively), which is consistent with our previous results (Julien et al., 2008; Phivilay et al., 2009).

\section{Transgenic PAK inactivation leads to a decrease of the postsynaptic protein drebrin}

So far, the results gathered from human samples and in the $3 \mathrm{xTg}-\mathrm{AD}$ mice strongly suggested a tight association between PAK and AD-like neuropathology, clinical symptoms, and electrophysiological defects, but did not infer a causal role of PAK. To discriminate whether alterations found in 3xTg-AD mice are dependent of PAK activity, we crossed the 3xTg-AD mice with dnPAK mice to generate heterozygous $3 \mathrm{xTg}-\mathrm{AD}$ mice with $\left(3 \mathrm{xTg}-\mathrm{AD}^{+/-} \times \mathrm{dnPAK}^{+/-}\right)$or without $\left(3 \mathrm{xTg}^{-\mathrm{AD}^{+/-}} \times \mathrm{dn}-\right.$ $\mathrm{PAK}^{-1-}$ ) PAK activity deficiencies.

Because the product of dnPAK transgene is labeled with a myc-tag sequence (Hayashi et al., 2004), we first performed immunofluorescence analysis using an antibody raised against anti $m y c$-tag. As expected, we observed a strong staining of the dnPAK transgene in $3 \times \mathrm{Tg}-\mathrm{AD}$ mice with genetically PAK inactivation, but no staining in $3 \times$ Tg-AD mice (Fig. $3 A$ ). This confirms that dnPAK expression was restricted to the cortex of $3 \mathrm{xTg}-\mathrm{AD} \times$ dnPAK mice in our study. Moreover, we observed a strong colocalization with the neuronal nuclei $(\mathrm{NeuN})$ protein, indicating that the dnPAK transgene was mostly expressed in neuronal cells (Fig. 3A). We next conducted immunohistofluorescence experiments using an antibody directed against pPAK (ser141, activated PAK). An apparent decrease of pPAK cortical staining was 
observed in $3 \mathrm{xTg}-\mathrm{AD} \times \mathrm{dnPAK}$ mice compared with $3 \times \mathrm{Tg}-\mathrm{AD}$ mice (Fig. $3 A$ ). Colocalization with NeuN labeling was also confirmed (Fig. 3A). Using Western blotting analysis, we found a decrease of phospho-PAK (ser141) in 3xTg- $\mathrm{AD}^{+/-} \times$ dnPAK $^{+/-}$at 12 and 20 months of age $(-27 \%$ and $-33 \%$, respectively, $p<$ 0.01 ), confirming the effectiveness of the dnPAK transgene in reducing PAK activation (Fig. 3B). A small compensatory upregulation of PAK1 $(+14 \%, p<0.05)$, but not PAK3, was observed in $3 \times \mathrm{Tg}$ $\mathrm{AD}^{+/-} \times \mathrm{dnPAK}^{+/-}$mice compared with $3 \times \mathrm{Tg}_{-} \mathrm{AD}^{+/-} \times \mathrm{dnPAK}^{-/-}$mice at 12 months, but not at 20 months (Fig. $3 C)$. dnPAK transgene expression did not induce any effect on detergent-soluble cofilin levels in 3xTg-AD mice regardless of their age (Fig. 3D). Despite a reduction with age (two-way ANOVA, $p=0.014$ ), no significant difference in phosphocofilin levels was detected between 3xTg-AD and 3xTg-AD $\times$ dnPAK mice. Nevertheless, PAK inactivation induced a $25 \%$ decrease of detergent-soluble drebrin level, a postsynaptic protein $(p<$ 0.05 ; Fig. $3 F$ ), in 20 -month-old $3 \times \mathrm{Tg}$ $\mathrm{AD}^{+1-} \times \mathrm{dnPAK}^{+1-}$ mice. This result was consistent with studies indicating that the membrane localization of drebrin is dependent on PAK activation (Zhao et al., 2006; Ma et al., 2008). Separate Western blot analyses showed that dnPAK expression in NonTg mice led to a nonsignificant trend toward a decrease of drebrin (2.68 \pm 0.62 in NonTg mice vs $1.35 \pm$ 0.26 in dnPAK mice, $n=6$ per group, $p=$ $0.0776)$. Although these data must be interpreted carefully due to low statistical power, they suggest that drebrin loss requires both PAK inactivation and $\mathrm{AD}$ neuropathology. Detergent-soluble levels of the presynaptic protein synaptophysin were also analyzed, but no significant change was observed whatever the age of 3xTg-AD mice (Fig. 3G).

PAK modulation can influence social recognition in 3xTg-AD mice

A battery of behavioral tests was performed to determine the cognitive impact of $\mathrm{dnPAK}$ expression in 3xAD-Tg mice. First, the general motor activity was found to be decreased in 3xTg-AD mice, but unaltered by PAK inactivation (Fig. $4 A, p<$ 0.05). Second, in the black and white box paradigm, animals from the three different groups spent similar time in the illuminated box (Fig. 4B). However, NonTg mice showed a higher number of alternances between compartments compared with $3 \times$ Tg-AD and $3 \times$ Tg-AD $\times$ dnPAK
A

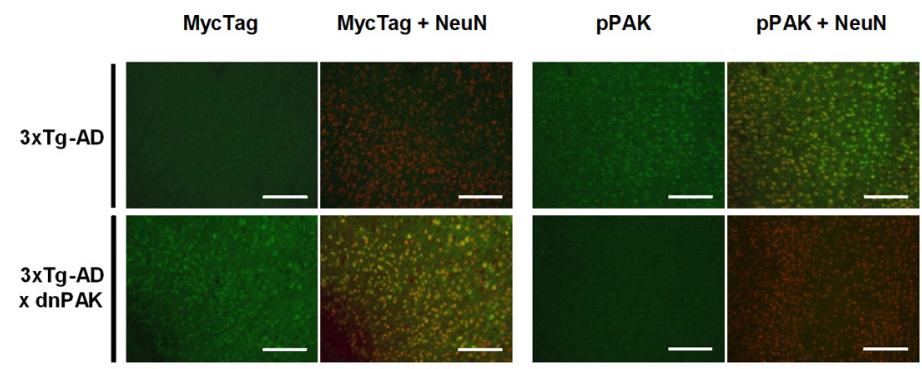

$3 \times \operatorname{Tg}-\mathrm{AD}(+/-) \times \mathrm{dnPAK}(-/-)$

$3 \times \operatorname{Tg}-\mathrm{AD}(+/-) \times \mathrm{dnPAK}(+/-)$
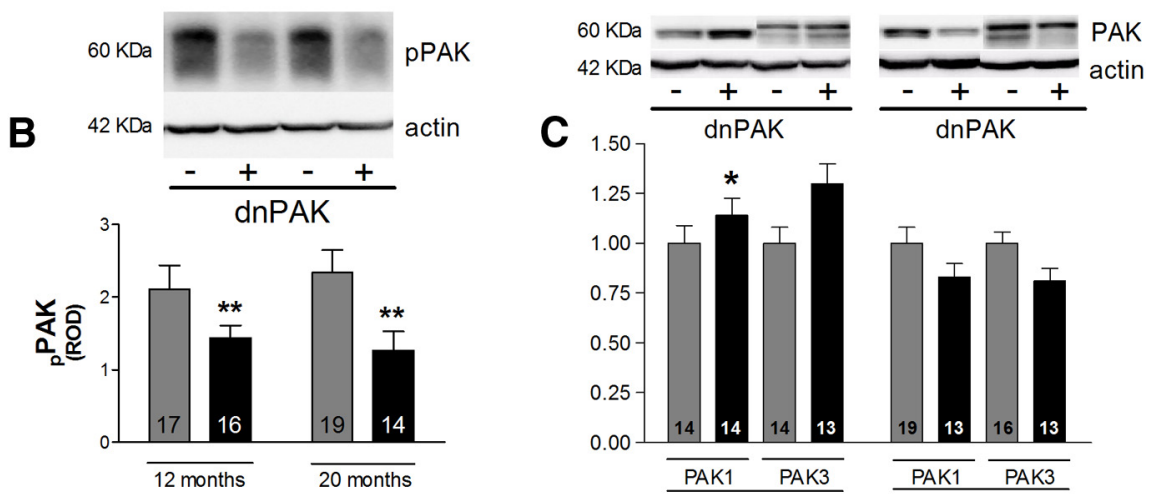

C 1.50
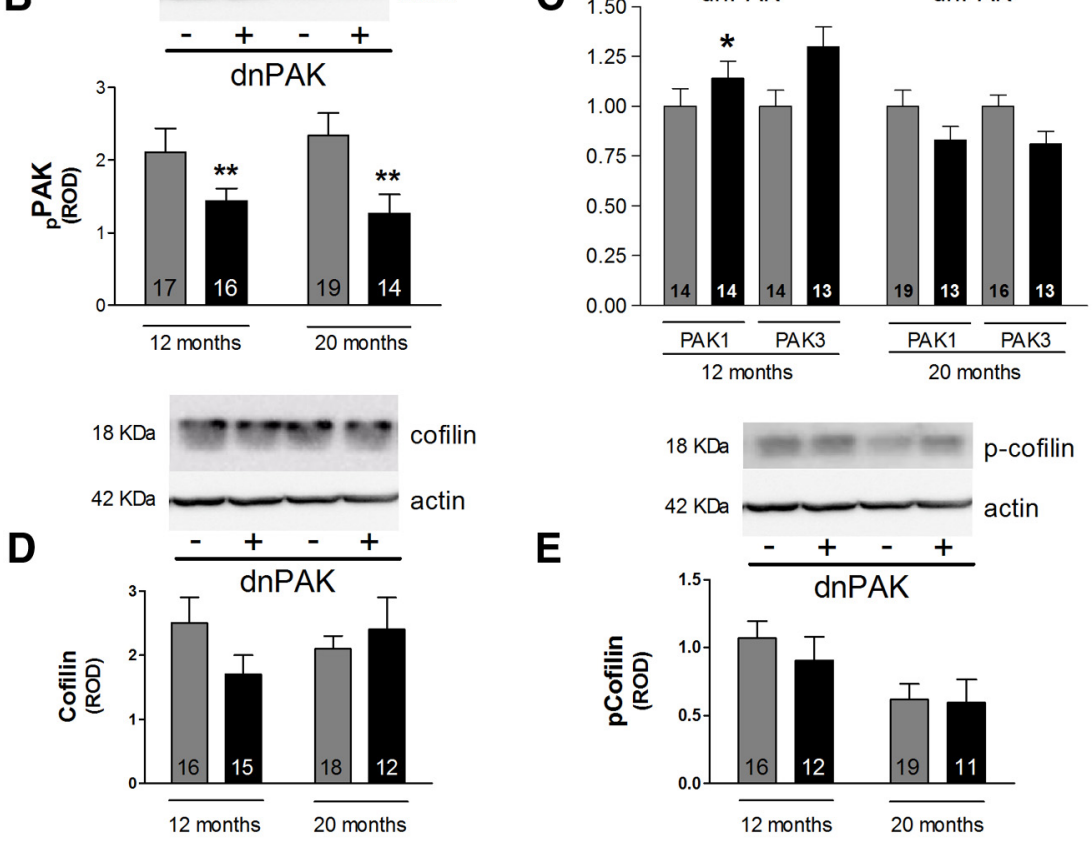

$\mathbf{E}$
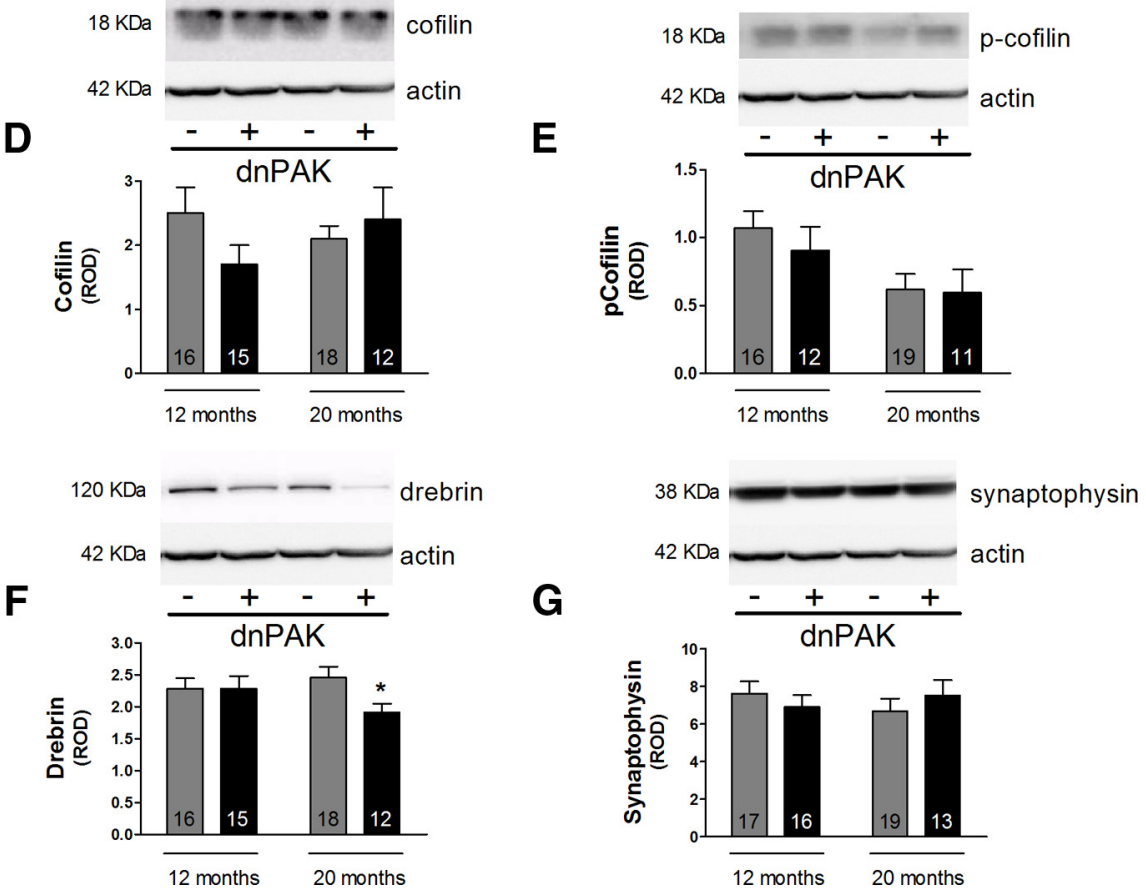

Figure 3. Consequences of PAK inactivation in 12- or 20-month-old heterozygous 3xTg-AD mice. $A$, Myc-Tag immunofluoresence (green) in the cortex confirmed that the dnPAK transgene was only expressed in neurons (NeuN in red) from $3 \times T_{g}-A D \times$ dnPAK mice compared with 3xTg-AD mice. pPAK immunostaining (green) in the cortex highlighted a neuronal localization (NeuN in red) of PPAK (s141) and an apparent decrease in 20-month-old 3xTg-AD mice with genetically PAK inactivation compared with $3 \times \operatorname{Tg}$-AD mice ( $n=3$ per group). Western blot analyses revealed that dnPAK transgene expression reduced pPAK $(\boldsymbol{B})$ and increased the level of $\mathrm{PAK}_{1}$ in 12-month-old mice, but was inefficient to modulate $\mathrm{PAK}_{3}$ at both ages $(\boldsymbol{C})$ in the soluble fraction. $\mathrm{dnPAK}$ transgene expression did not induce any effect on cofilin $(\boldsymbol{D})$ or phospho-cofilin $(\boldsymbol{E})$ levels in the cortex of 3xTg-AD mice. Interestingly, drebrin level was reduced in 20-month-old mice in the membrane fraction $(\boldsymbol{F})$. Finally, no significant effect was observed on detergent-soluble synaptophysin level whatever the age of mice $(\boldsymbol{G})$. Square bar equals $100 \mu \mathrm{m}$. Values are expressed as mean \pm SEM. Statistical analyses were performed using an unpaired $t$ test. For PAK3 analysis (C), only the upper band was used. ${ }^{*} p<0.05$, ${ }^{* *} p<0.01$. 
A
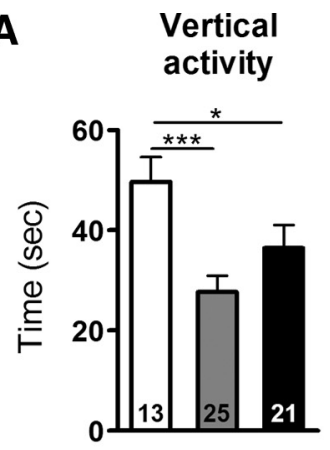

B

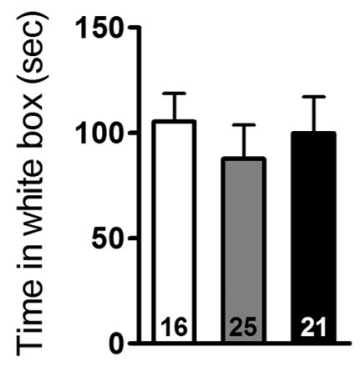

C

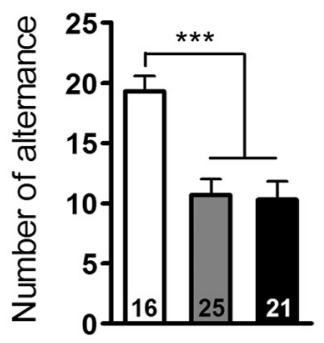

Black and white box
D

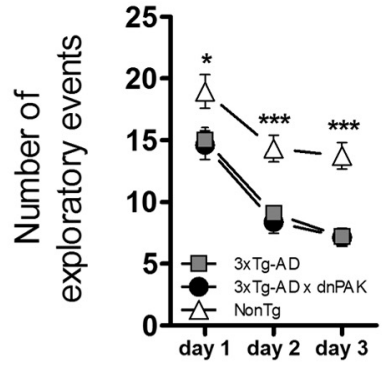

E



$\mathbf{F}$

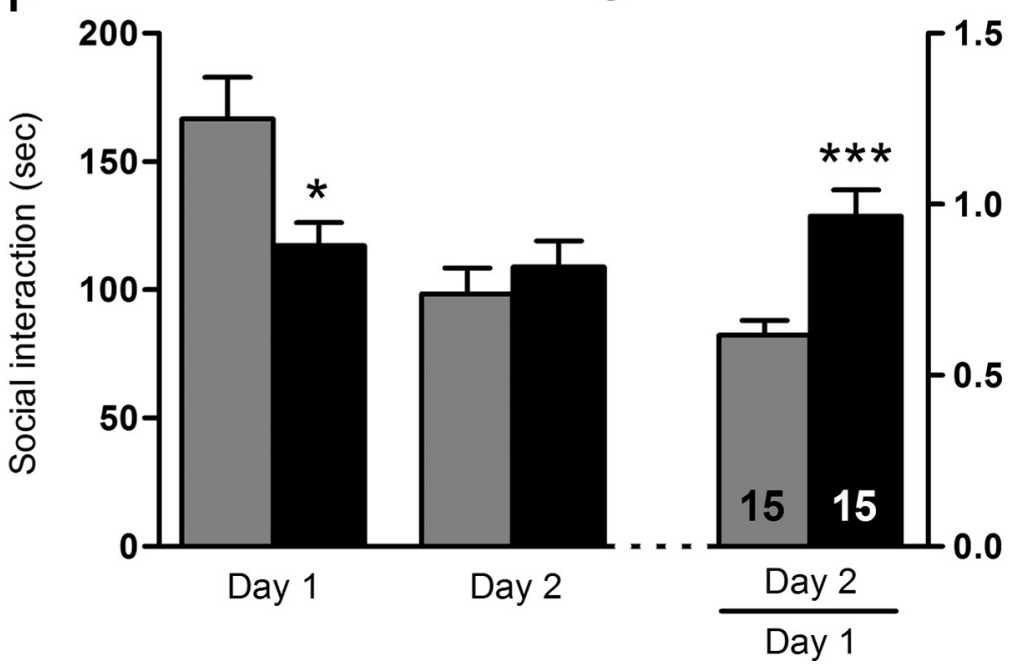

Figure 4. PAK inactivation impaired social recognition in 20-month-old 3xTg-AD mice. (A) NonTg mice showed higher general activity than 3xTg-AD mice, as reflected in a vertical activity test over a 10 min observation span. $B$, Time spent in the illuminated compartment of the black and white box was not significantly different in NonTg, 3xTg-AD, and 3xTg-AD $\times$ dnPAK mice. C, 3xTg-AD and 3xTg-AD $\times$ dnPAK mice showed a similar number of alternances, but both were lower than NonTg, suggesting that the level of anxiety was not influenced by PAK inhibition. $\boldsymbol{D}$, Exploratory behavior was similarly decreased in $3 \times \mathrm{XTg}-\mathrm{AD}$ and $3 \times \mathrm{Tg}-\mathrm{AD} \times$ dnPAK mice compared with NonTg animals. $\boldsymbol{E}$, Social events in which a mouse interacts with its dyad partner were recorded (sniffing, following, grooming the partner, crawling over or under) at day 1 and at day 2.F, 3xTg-AD mice with normal PAK activity had a 40\% reduction of interaction time with their dyad mate at day 2 compared with day 1. In contrast, PAK-deficient 3xTg-AD mice displayed the same interaction time with their partner at day 1 and day 2, consistent with a complete absence of social recognition. Values are expressed as mean \pm SEM. Statistical comparisons were performed using an unpaired Student's $t$ test. ${ }^{*} p<0.05,{ }^{* * *} p<0.001$.

mice (Fig. $4 C, p<0.001$ ). Therefore, our results are suggestive of a higher anxiety level in 3xTg-AD mice, which, however, remained unaffected by the expression of dnPAK. Spontaneous exploration in a new environment was also evaluated. All animals showed a normal decrease of their exploratory behavior in the second and the third day compared with the first (Fig. 4D). The number of exploratory events recorded was lower in both $3 \times \mathrm{Tg}-\mathrm{AD}$ and $3 \mathrm{xTg}-\mathrm{AD} \times \mathrm{dnPAK}$ mice compared with NonTg mice (Fig. 4D). Therefore, as described previously (Arsenault et al., 2011; Bories et al., 2012), 3xTg-AD transgenes decreased the motivation to explore a new environment (Fig. 4D), a behavior that remained unaltered by the expression of dnPAK.

To determine whether PAK inactivation translated into social behavior defects, the capacity of groups of animals to recognize their peers was documented. To assess sociability in animal models, several behavioral tests have been developed (for review, see Silverman et al., 2010). The social recognition test is based on the propensity of an adult mouse to spend more time interacting with an unknown mouse than with a known mouse (Winslow, 2001; Kaidanovich-Beilin et al., 2011; Fig. 4E) and is frequently used to show memory impairments in rodents (Winslow, 2001; Bilkei-Gorzo et al., 2005; Zhao et al., 2006). Our data revealed a significant increase of the social recognition ratio in $3 \mathrm{xTg}^{-\mathrm{AD}^{+/-}} \times$
dnPAK ${ }^{+/-}$mice compared with $3 \mathrm{xTg}^{-\mathrm{AD}^{+/-}} \times \mathrm{dnPAK}^{-1-}$ mice at 20 months of age $(+56 \%, p<0.001$; Fig. $4 F)$, which was not explained by changes in motor performances, motivation, or anxiety levels (Fig. $4 A-D$ ). In other words, social interactions with a known partner were not reduced in $3 \mathrm{xTg}^{-\mathrm{AD}^{+/-}} \times$ $\mathrm{dnPAK}^{+/-}$mice on day 2 compared with day 1 , whereas a clear decrease in social interactions was noted in $3 \times \mathrm{Tg}^{-\mathrm{AD}^{+/}} \times \mathrm{dn}-$ $\mathrm{PAK}^{-1-}$ mice. Therefore, disrupted PAK activity led to a complete loss of social recognition in $3 \mathrm{xTg}^{\mathrm{A}} \mathrm{AD}^{+/-} \times \mathrm{dnPAK}^{+/-}$mice.

Transgenic PAK inactivation leads to a transient decrease of $\mathrm{A} \boldsymbol{\beta}$ and tau deposition

To determine whether PAK plays a causal or amplifying role in the development of neuropathological markers of $\mathrm{AD}$, we quantified $A \beta$ and tau in the soluble and insoluble fractions of parietotemporal cortex of 12- or 20-month-old 3xTg-AD mice with or without concomitant dnPAK transgene expression. We first found that PAK inactivation did not affect the soluble levels of $\mathrm{A} \beta 40$ and $\mathrm{A} \beta 42$ in $3 \mathrm{xTg}$-AD mice (Fig. $5 A, B$ ). However, PAK dysfunction significantly reduced the amount of both $\mathrm{A} \beta 40$ and $\mathrm{A} \beta 42$ in the insoluble fraction in $3 \mathrm{xTg}-\mathrm{AD}^{+/-} \times \mathrm{dnPAK}^{+/-}$ mice at 12 months of age $(-35 \%$ for both, $p<0.05)$, but not at 20 
months of age (Fig. 5C,D). In addition, we observed a $58 \%$ decrease of insoluble/ soluble tau ratio in $3 \times \mathrm{xg}^{-\mathrm{AD}^{+/-}} \times$ dnPAK ${ }^{+/-}$mice compared with $3 \times \mathrm{Tg}$ $\mathrm{AD}^{+/-} \times \mathrm{dnPAK}^{-/-}$mice at the age of 12 months $(p<0.01$; Fig. $5 E)$. Again, this decrease was ultimately lost at 20 months of age (Fig. 5E). No significant changes were observed in the soluble phosphotau/soluble tau ratio or the concentration of insoluble phospho-tau (Fig. 5F, G). These experiments suggest that a reduction in brain PAK activity can exert a beneficial effect on $\mathrm{A} \beta$ and tau deposition, at least transiently, and that the disruptive effect of PAK inactivation on social recognition does not require an enhancement of $A \beta$ and tau deposition in the brains of $3 \mathrm{xTg}-\mathrm{AD}$ mice.

Loss of $C C$ and hyperactivity of excitatory synapses in 3xTg-AD mice were not influenced by PAK activity

As reported previously (Arsenault et al., 2011), entorhinal cortex deep layer neurons of 12-month-old homozygous 3xTg-AD mice present normal resting potential (Fig. $6 A$ ) and decreased $C C$ (Fig. 6B). Interestingly, here we found a strong positive correlation between soluble total PAK and the CC (Fig. 6C). In addition, the frequency of sEPSC recordings was higher in $3 x T g-A D$ neurons (Fig. 6D,F), whereas their amplitudes were lower (Fig. 6E,F). This suggests that homozygous $3 \mathrm{xTg}-\mathrm{AD}$ cortical neurons display abnormalities of intrinsic or synaptic properties that are associated with PAK concentrations.

To further investigate the electrophysiological function of PAK in $\mathrm{AD}$, we studied the effect of PAK inactivation on the same intrinsic and synaptic properties of deep-layer lateral entorhinal cortex neurons of NonTg mice $\left(3 \mathrm{xTg}-\mathrm{AD}^{-1-} \times\right.$ $\mathrm{dnPAK}^{-1-}$ ), heterozygous 3xTg-AD mice $\left(3 \mathrm{xTg}-\mathrm{AD}^{+/-} \times \mathrm{dnPAK}^{-/-}\right)$, and heterozygous $3 \mathrm{xTg}-\mathrm{AD}$ mice with a deficiency of PAK activity $\left(3 \mathrm{xTg}-\mathrm{AD}^{+/-} \times \mathrm{dnPAK}^{+/-}\right)$. We first confirmed that dnPAK expression in NonTg mice had no effect on each intrinsic parameter under study (Fig. 6) and then showed that neurons from heterozygous

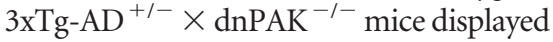
decreased $C C$ and higher sEPSC frequencies compared with NonTg mice (Fig. 6 H, I, respectively), as shown previously in homozygous 3xTg-AD mice, but without any change in their resting potential (Fig. $6 G$ ). However, we found that $C C$ and sEPSC frequencies of entorhinal cortex neurons in $3 \mathrm{xTg}-\mathrm{AD}$ mice remained unchanged with PAK inactivation (Fig. 6H,I, respectively). Finally, we did not find any difference in the mean amplitude of sEPSCs between groups (Fig. 6J). These results suggest that the effects of PAK inactivity on social recognition are not related to the electrophysiological parameters altered in 3xTg-AD animals evaluated here.
A

C

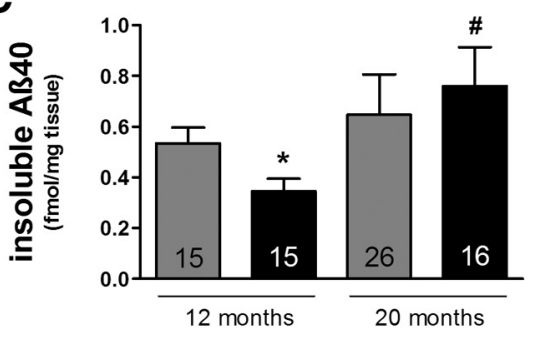

E
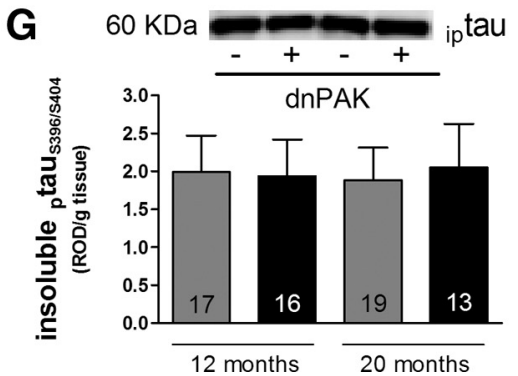

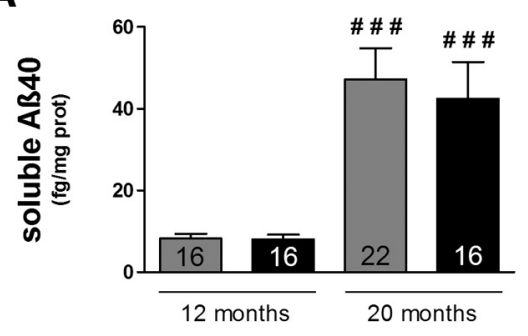

B

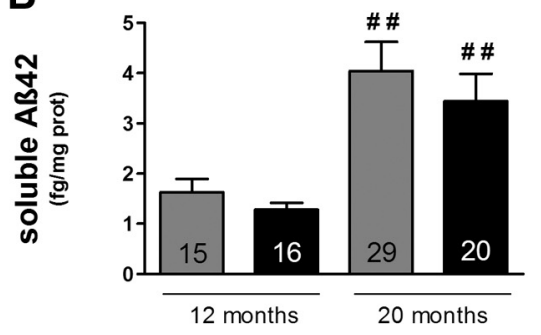

D

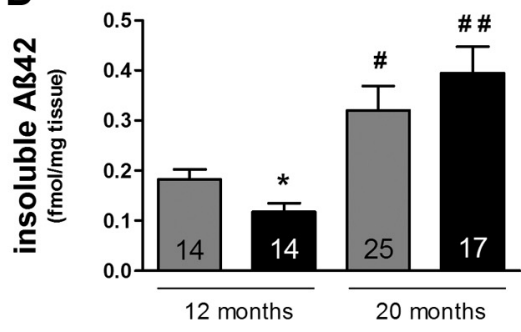

$\mathbf{F}$
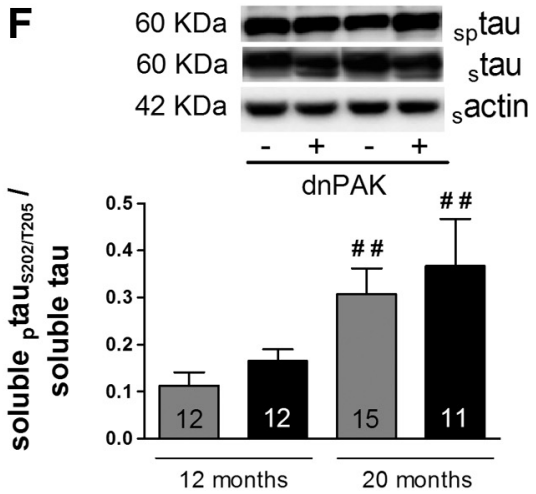

Figure 5. PAK inactivation reduced $A \beta$ and tau depositions in 12-and 20-month-old heterozygous $3 \times$ Tg-AD mice. PAK inactivation did not alter concentrations of $\mathrm{s} A 340(\boldsymbol{A})$ and $\mathrm{s} A \beta 42(\boldsymbol{B})$ in soluble fractions at any age, but decreased $\mathrm{i} A \beta 40(\boldsymbol{C})$ and iA $\beta 42$ (D) levels in insoluble fractions from 12-month-old 3xTg-AD mice. Whereas the inactivation of PAK induced a decrease of the insoluble/soluble tau ratio in 12-month-old mice $(\boldsymbol{E})$, it did not induced any effect on the soluble phospho-tau/total tau ratio in mice whatever their age $(\boldsymbol{F})$. Finally, no effect was observed on phospho-tau levels in the insoluble fraction $(\boldsymbol{G})$. Values are expressed as mean \pm SEM. Statistical comparisons were performed using an unpaired $t$ test. ROD indicates relative optical density. Comparison between genotype: ${ }^{*} p<0.05,{ }^{* *} p<0.01$; comparison between age: ${ }^{\#} p<0.05,{ }^{\# \#} p<0.01,{ }^{\# \# \#} p<0.001$.

\section{Discussion}

This study shows that the postmortem PAK concentrations in the cortex of $\mathrm{AD}$ patients are strongly associated with the clinical and neuropathological expression of the disease (Fig. 7). The decrease in PAK can be replicated in animal models transgenically designed to develop $\mathrm{A} \beta$ and tau pathologies. Expression of the dnPAK transgene in 3xTg-AD mice led to reduced PAK activation, as observed in $\mathrm{AD}$ patients. However, this did not aggravate $\mathrm{A} \beta$ or tau pathologies, suggesting that the loss of PAK lies downstream of these canonical AD markers. More strikingly, despite no direct deteriorating effects 


\section{Changes in passive and active intrinsic properties in homozygous 3xTg-AD mice}

A

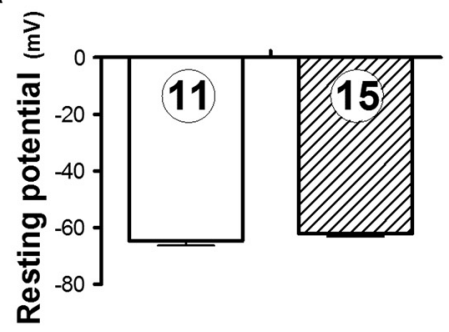

D



B

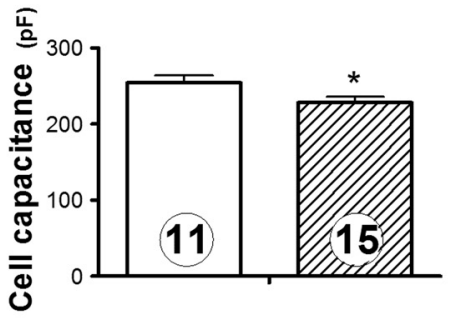

E

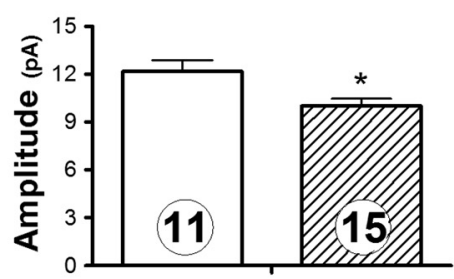

C

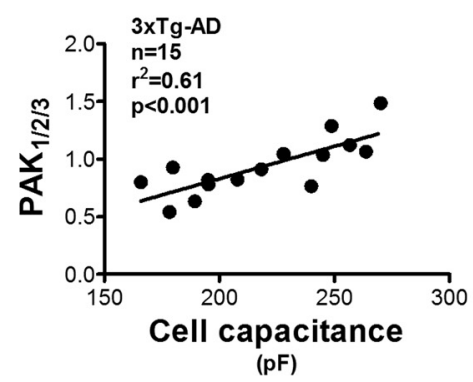

$\mathbf{F}$

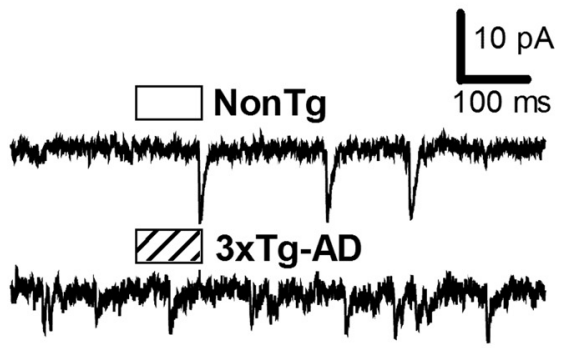

\section{PAK inactivation had limited impact on altered intrinsic properties in heterozygous $3 \times \mathrm{Tg}-\mathrm{AD}$ mice}

\section{G}

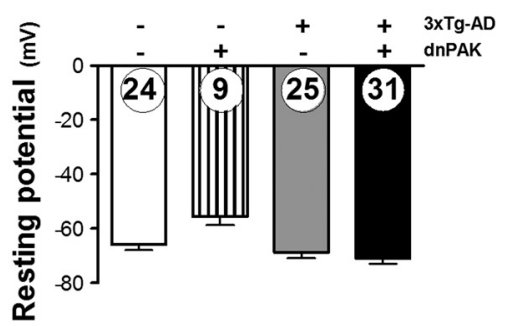

I

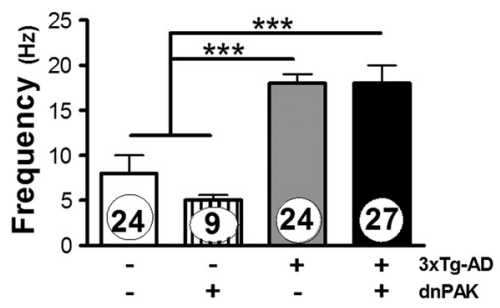

H

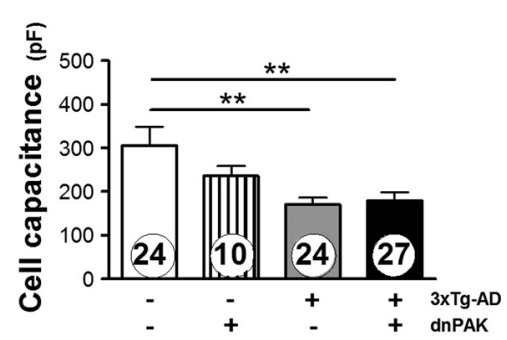

$\mathbf{J}$

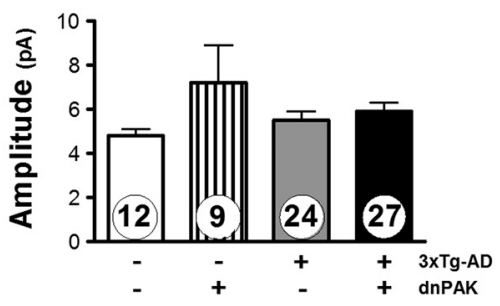

K



Figure 6. Intrinsic properties of entorhinal cortex neurons in 12-month-old homozygous 3xTg-AD mice and in 20-month-old 3xTg-AD mice with genetically induced PAK inactivation. $\boldsymbol{A}-\boldsymbol{F}$, Expression of transgenes in homozygous $3 \times \mathrm{Tg}$-AD mice did not change resting potential $(\boldsymbol{A})$ but decreased $C(\boldsymbol{B})$ of entorhinal cortex deep layer neurons. Interestingly, we found a positive correlation between soluble PAK $_{1 / 2 / 3}$ and the CC(C). Events of sEPSC occurred more frequently in 3xTg-AD neurons (D), but event amplitudes were lower (E). $\boldsymbol{F}$, Examples of spontaneous EPSC recordings made in NonTg and 3xTg-AD neurons. NonTg mice are represented in white and 3xTg-AD mice are represented by stripes in graphs. $\mathbf{G}-\boldsymbol{K}$, To investigate the physiological function of PAK in AD, we studied effects of PAK inactivation in intrinsic and synaptic properties of deep-layer lateral entorhinal cortex neurons of NonTg (white), NonTg with a deficiency in PAK activity (white with black stripes), heterozygous 3xTg-AD (gray), and heterozygous 3xTg-AD mice with a deficiency of PAK activity (black). Genetically, PAK inactivation in NonTg or 3xTg-AD mice did not influence impairments of passive properties of entorhinal cortex observed in 3xTg-AD mice, as reflected by resting potential $(\boldsymbol{G})$ and $C C(\boldsymbol{H})$ analyses. Similarly, frequency $(\boldsymbol{I})$ and amplitude $(\boldsymbol{J})$ of sEPSCs observed in $3 \times \mathrm{Tg}$-AD mice were not influenced by PAK activity. $\boldsymbol{K}$, Examples of sEPSC recordings made in NonTg, 3XTg-AD, and PAK-deficient 3XTg-AD neurons. Values are expressed as mean \pm SEM of the numbers of cells analyzed. Statistical analyses were performed using unpaired $t$ test. ${ }^{*} p<0.05,{ }^{* *} p<0.01,{ }^{* * *} p<0.001$.

of PAK dysfunction on CC or synaptic activity in 3xTg-AD mice, a loss of PAK activity obliterated their social recognition capacity, a behavior defect reminiscent of a common symptom of AD (Larson et al., 1992). Therefore, although our study does not pinpoint PAK dysfunction as an early causal mechanistic event in $\mathrm{AD}$, it suggests that PAK activity is essential for the maintenance of social recognition functions that are severely compromised in $\mathrm{AD}$.
PAK alteration in AD

In the present study, the diagnosis of $\mathrm{AD}$ was associated with lower PAK and phospho-PAK concentrations in the parietal cortex. This is in agreement with previous Western blot and immunostaining analyses performed in the cortex and hippocampus of $\mathrm{AD}$ patients (Zhao et al., 2006; Ma et al., 2008; Nguyen et al., 2008). However, no significant difference in PAK was detected in individ- 


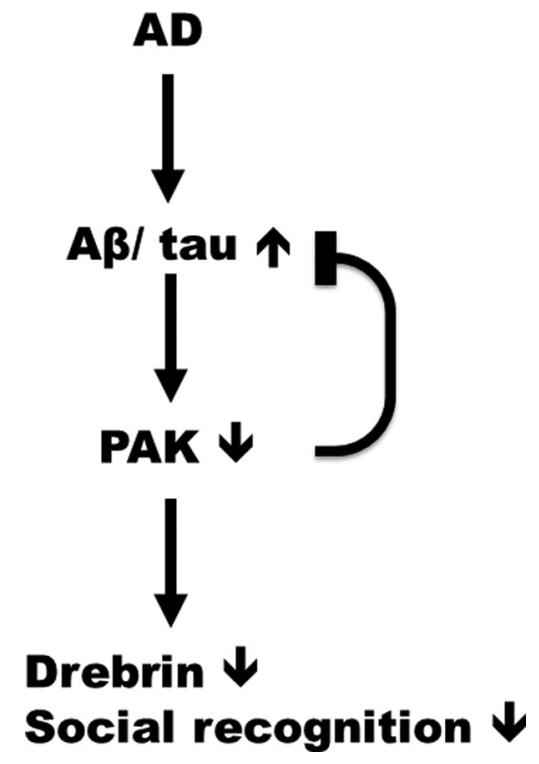

Figure 7. Counterbalancing the loss of PAK might be of therapeutic value in AD. Late during AD progression, and not in individuals with mild cognitive impairment, the levels of PAK decrease in the brain in close relationship with accumulation of tau neuropathology and declining cognitive performance. In the $3 \times T g-A D$ mouse model, expression of transgenes leading to $A \beta$ and tau pathologies induced a global decrease of PAK. Conversely, genetic deactivation of PAKin the 3xTg-AD mouseled to a transient decrease in insoluble $A \beta$ and tau. This suggests that PAK decrease is a consequence rather than a cause of $A \beta$ and tau neuropathologies. However, inactivating PAK in the brains of 3xTg-AD mice generated an animal model closer to $A D$ by decreasing drebrin levels and social recognition capacities. Overall, our study supports the hypothesis that a therapeutic intervention aimed at increasing PAK activity may improve $A D$ symptoms without correcting $A \beta$ and tau pathologies.

uals with mild cognitive impairment, suggesting that the loss of PAK is a relatively late event. Therefore, our results indicate that a decrease in PAK concentration is closely associated with both clinical symptoms and $A \beta /$ tau neuropathologies and argue in favor of an important role of PAK in the disease progression.

\section{Impairments of $\mathrm{PAK}$ observed in $\mathrm{AD}$ patients are partly replicated in 3xTg-AD mice}

The 3xTg-AD mouse simultaneously expresses tau and $\mathrm{A} \beta$ pathologies and is therefore used to model AD (Oddo et al., 2003a). We observed a loss of PAK in 3xTg-AD mice at 12 and 20 months of age, but not at 4 months, indicating that PAK is affected by age, a key factor in the development of AD. This result also demonstrates that the loss of soluble PAK in $3 x T g-A D$ mice is not the result of an interaction between transgene expression and developmental processes, because the loss of the protein occurs in adult mice. Interestingly, the loss of PAK coincides with the age when the animal presents abundant deposition of insoluble proteins (i.e., 12 months; Oddo et al., 2003a; Julien et al., 2008). Our results indicate that the $3 \mathrm{xTg}-\mathrm{AD}$ model replicates $\mathrm{PAK}$ abnormalities found in $\mathrm{AD}$, but, consistent with the human data, these observations in animals strongly suggest that the loss of PAK is a consequence rather than a cause of AD neuropathology.

\footnotetext{
Downstream alterations of drebrin and cognitive impairment in AD: a consequence of PAK dysfunction?

PAK is essential to the maturation and maintenance of dendritic spines and its dysfunction leads to cognitive impairments through a disruption of actin scaffold within dendrites (Zhao et al., 2006). PAK dysfunction induces downstream cofilin activation, actin filament depolymerization, drebrin displacement, and, ultimately, defects in spine dynamics (Minamide et al., 2000;
}

Bokoch, 2003; Zhao et al., 2006; Kreis and Barnier, 2009). This hypothesis is supported by data in cultured hippocampal cells and in rodents, in which intracerebral injections of PAK inhibitors induced the translocation of drebrin from the membrane to the cytosol (Zhao et al., 2006; Ma et al., 2008). Incidentally, a loss of drebrin in the membrane compartment of the brain of $\mathrm{AD}$ patients has been consistently observed by various groups using different methodologies (Shim and Lubec, 2002; Calon et al., 2004; Counts et al., 2006; Aoki et al., 2007; Lacor et al., 2007; Julien et al., 2008). A decrease in drebrin in the membrane fractions can also be detected in the brain of $\mathrm{AD}$ transgenic mouse models, particularly after exposure to dietary risk factors (Calon et al., 2004; Julien et al., 2010). Therefore, the specific loss of detergent-soluble drebrin observed here after chronic PAK inactivation is consistent with drebrin being a downstream element of PAK signalization. In contrast, consistent with previous studies performed in AD patients and mouse models (Zhao et al., 2006; Kang et al., 2011), no changes in cofilin and phospho-cofilin concentrations were observed in our study.

Because PAK is essential for cognitive performance in animals (Ramakers, 2002; Meng et al., 2005; Zhao et al., 2006; Nekrasova et al., 2008) and humans (Boda et al., 2004; Zhao et al., 2006; Morrow et al., 2008; Nikolić, 2008), one could assume that a loss of PAK activity is detrimental. The loss of drebrin observed here, as in $\mathrm{AD}$, is consistent with such a hypothesis (Zhao et al., 2006; Kojima and Shirao, 2007; Kojima et al., 2010; VanGuilder et al., 2012). Social interaction is a fundamental and adaptive component of the biology in numerous species. In mice, recognition of conspecifics may be important for maintaining social hierarchy and for mate choice (Kaidanovich-Beilin et al., 2011). Two unfamiliar mice placed in a neutral arena will usually display important interactions (Kwon et al., 2006). Our results showed a profound social-cognitive impairment in the $3 \times \mathrm{Tg}$-AD mice with PAK dysfunction, suggesting that PAK activity is critical to the maintenance of these higher social functions. Previous work showed that dnPAK mice exhibit specific deficits in the consolidation phase of hippocampus-dependent memory (Hayashi et al., 2004), suggesting that the loss of social recognition is a consequence of memory impairment. Finally, the impaired social recognition functions and drebrin loss observed suggest that the $3 \mathrm{xTg}-\mathrm{AD}^{+/-} \times \mathrm{dnPAK}^{+/-}$mouse may mimic more closely the human disease.

\section{PAK inactivation does not promote the formation of insoluble depots of $A \beta$ and tau}

To determine whether PAK is a cause or a consequence of $\mathrm{AD}$ neuropathology, we investigated the effect of a genetically induced PAK dysfunction on $\mathrm{A} \beta$ and tau concentrations in the $3 x T g-A D$ mouse model. Potentiation of AD-like neuropathology in $3 \mathrm{xTg}-\mathrm{AD}^{+/-} \times \mathrm{dnPAK}^{+/-}$mice would have been consistent with a benefic action of PAK. However, in our study, PAK inactivation rather led to a diminution of insoluble $A \beta$ and tau in 12 -month-old animals, an effect shown to be transient because it was lost at 20 months of age. It is important to underscore that the causal role of both $\mathrm{A} \beta$ and tau neuropathologies in $\mathrm{AD}$ remains unclear and relies mostly on correlative clinicopathology (Steinerman et al., 2008; Nelson et al., 2012) or genetic studies (Götz et al., 2008; O'Brien and Wong, 2011). The present data indicate that PAK may play a role in the formation of insoluble $A \beta$ or tau deposits, and thus deserve further investigation. For example, PAK targeting could be used to modulate the aggregation of proteins into their insoluble form. These data chiefly indicate that the disruptive effect of PAK inactivation on social recognition does 
not require any clear enhancement of $\mathrm{A} \beta$ and tau deposition in the 3xTg-AD mouse model.

\section{Electrophysiological abnormalities in 3xTg-AD are not modulated by PAK}

Electrophysiological abnormalities such as a loss of $C C$ and increased frequency of sEPSCs were described recently in 3xTg-AD mice (Arsenault et al., 2011). These observations are consistent with a study showing that $\mathrm{A} \beta$ peptide could enhance sEPSCs (Abramov et al., 2009 ), leading to a vicious cycle because synaptic activity is known to stimulate the production of $A \beta$ peptides (Kamenetz et al., 2003). CC is a well accepted indication of the membrane surface area of the patched cell (Golowasch et al., 2009; Arsenault et al., 2011). The decrease in $C C$ observed in 3xTg-AD animals may reflect neuronal atrophy (Golowasch et al., 2009), as reported previously in 3xTg-AD mice (Arsenault et al., 2011). The strong relationship between PAK levels and the decrease of $C C$ in entorhinal cortical neurons prompted us to investigate the effect of PAK inactivation on this neuronal population.

Our patch-clamp experiments in 20-month-old heterozygous $3 \times \mathrm{Tg}^{-} \mathrm{AD}^{+/-} \times \mathrm{dnPAK}^{+/-}$mice confirmed what has been found earlier in homozygous 3xTg-AD mice: a decrease in $C C$ and an increase of sEPSCs. However, PAK dysfunction did not correct or aggravate $C C$ or synaptic current changes in the $3 \times \mathrm{Tg}-\mathrm{AD}$ mouse, suggesting that PAK impairments are either downstream of or occur in parallel with these electrophysiological abnormalities. In summary, our results suggest that the social recognition deficit induced by PAK inactivation in 3xTg-AD mice is more likely to be related to defect in PAK-drebrin signaling rather than to changes in basic neuron physiology.

Overall, the human and animal data show that a loss of PAK is associated with $\mathrm{AD}$ and is therefore likely a consequence rather than a cause of $\mathrm{A} \beta$ and tau neuropathology. Transgenic deactivation of PAK in the brain led to AD-like obliteration of social recognition in 3xTg-AD mice without either enhancing brain $A \beta /$ tau pathologies or leaving a clear electrophysiological signature in neurons. Although the PAK loss does not appear to play a causal role in $\mathrm{AD}$ pathogenesis, our results suggest that increasing the activation of the PAK molecular cascade may prove beneficial against cognitive or neuropsychiatric symptoms of AD.

\section{References}

Abramov E, Dolev I, Fogel H, Ciccotosto GD, Ruff E, Slutsky I (2009) Amyloid-beta as a positive endogenous regulator of release probability at hippocampal synapses. Nat Neurosci 12:1567-1576. CrossRef Medline

Ackl N, Ising M, Schreiber YA, Atiya M, Sonntag A, Auer DP (2005) Hippocampal metabolic abnormalities in mild cognitive impairment and Alzheimer's disease. Neurosci Lett 384:23-28. CrossRef Medline

Aoki C, Mahadomrongkul V, Fujisawa S, Habersat R, Shirao T (2007) Chemical and morphological alterations of spines within the hippocampus and entorhinal cortex precede the onset of Alzheimer's disease pathology in double knock-in mice. J Comp Neurol 505:352-362. CrossRef Medline

Arsenault D, Zhang ZW (2006) Developmental remodelling of the lemniscal synapse in the ventral basal thalamus of the mouse. J Physiol 573:121-132. CrossRef Medline

Arsenault D, Julien C, Tremblay C, Calon F (2011) DHA improves cognition and prevents dysfunction of entorhinal cortex neurons in 3xTg-AD mice. PLoS One 6:e17397. CrossRef Medline

Bennett DA (2006) Postmortem indices linking risk factors to cognition: results from the Religious Order Study and the Memory and Aging Project. Alzheimer Dis Assoc Disord 20:S63-68. CrossRef Medline

Bennett DA, Wilson RS, Schneider JA, Evans DA, Beckett LA, Aggarwal NT, Barnes LL, Fox JH, Bach J (2002) Natural history of mild cognitive impairment in older persons. Neurology 59:198-205. CrossRef Medline
Bennett DA, Schneider JA, Bienias JL, Evans DA, Wilson RS (2005) Mild cognitive impairment is related to Alzheimer disease pathology and cerebral infarctions. Neurology 64:834-841. CrossRef Medline

Bilkei-Gorzo A, Racz I, Valverde O, Otto M, Michel K, Sarstre M, Zimmer A (2005) Early age-related cognitive impairment in mice lacking cannabinoid CB1 receptors. Proc Natl Acad Sci U S A 102:15670-15675. CrossRef Medline

Boda B, Alberi S, Nikonenko I, Node-Langlois R, Jourdain P, Moosmayer M, Parisi-Jourdain L, Muller D (2004) The mental retardation protein PAK3 contributes to synapse formation and plasticity in hippocampus. J Neurosci 24:10816-10825. CrossRef Medline

Boda B, Nikonenko I, Alberi S, Muller D (2006) Central nervous system functions of PAK protein family: from spine morphogenesis to mental retardation. Mol Neurobiol 34:67-80. CrossRef Medline

Bokoch GM (2003) Biology of the p21-activated kinases. Annu Rev Biochem 72:743-781. CrossRef Medline

Bories C, Guitton MJ, Julien C, Tremblay C, Vandal M, Msaid M, De Koninck Y, Calon F (2012) Sex-dependent alterations in social behaviour and cortical synaptic activity coincide at different ages in a model of Alzheimer's disease. PLoS One 7:e46111. CrossRef Medline

Bourin M, Hascoët M (2003) The mouse light/dark box test. Eur J Pharmacol 463:55-65. CrossRef Medline

Boyle PA, Wilson RS, Aggarwal NT, Tang Y, Bennett DA (2006) Mild cognitive impairment: risk of Alzheimer disease and rate of cognitive decline. Neurology 67:441-445. CrossRef Medline

Calon F, Morissette M, Rajput AH, Hornykiewicz O, Bédard PJ, Di Paolo T (2003) Changes of GABA receptors and dopamine turnover in the postmortem brains of parkinsonians with levodopa-induced motor complications. Mov Disord 18:241-253. CrossRef Medline

Calon F, Lim GP, Yang F, Morihara T, Teter B, Ubeda O, Rostaing P, Triller A, Salem N Jr, Ashe KH, Frautschy SA, Cole GM (2004) Docosahexaenoic acid protects from dendritic pathology in an Alzheimer's disease mouse model. Neuron 43:633-645. CrossRef Medline

Counts SE, Nadeem M, Lad SP, Wuu J, Mufson EJ (2006) Differential expression of synaptic proteins in the frontal and temporal cortex of elderly subjects with mild cognitive impairment. J Neuropathol Exp Neurol 65: 592-601. CrossRef Medline

Crawley JN (1985) Exploratory behavior models of anxiety in mice. Neurosci Biobehav Rev 9:37-44. Medline

Dubos A, Combeau G, Bernardinelli Y, Barnier JV, Hartley O, Gaertner H, Boda B, Muller D (2012) Alteration of Synaptic Network Dynamics by the Intellectual Disability Protein PAK3. J Neurosci 32:519-527. CrossRef Medline

Golowasch J, Thomas G, Taylor AL, Patel A, Pineda A, Khalil C, Nadim F (2009) Membrane capacitance measurements revisited: dependence of capacitance value on measurement method in nonisopotential neurons. J Neurophysiol 102:2161-2175. CrossRef Medline

Götz J, Ittner LM, Schonrock N, Cappai R (2008) An update on the toxicity of Abeta in Alzheimer's disease. Neuropsychiatr Dis Treat 4:1033-1042. CrossRef Medline

Harris JA, Devidze N, Verret L, Ho K, Halabisky B, Thwin MT, Kim D, Hamto P, Lo I, Yu GQ, Palop JJ, Masliah E, Mucke L (2011) Transsynaptic progression of amyloid-beta-induced neuronal dysfunction within the entorhinal-hippocampal network. Neuron 68:428-441. CrossRef Medline

Hayashi ML, Choi SY, Rao BS, Jung HY, Lee HK, Zhang D, Chattarji S, Kirkwood A, Tonegawa S (2004) Altered cortical synaptic morphology and impaired memory consolidation in forebrain-specific dominantnegative PAK transgenic mice. Neuron 42:773-787. CrossRef Medline

Hayashi ML, Rao BS, Seo JS, Choi HS, Dolan BM, ChoiSY, ChattarjiS, Tonegawa S (2007) Inhibition of p21-activated kinase rescues symptoms of fragile X syndrome in mice. Proc Natl Acad Sci U S A 104:11489-11494. CrossRef Medline

Heredia L, Helguera P, de Olmos S, Kedikian G, Solá Vigo F, LaFerla F, Staufenbiel M, de Olmos J, Busciglio J, Cáceres A, Lorenzo A (2006) Phosphorylation of Actin-Depolymerizing Factor/Cofilin by LIMKinase Mediates Amyloid beta-Induced Degeneration: A Potential Mechanism of Neuronal Dystrophy in Alzheimer's Disease. J Neurosci 26:6533-6542. CrossRef Medline

Huang W, Zhou Z, Asrar S, Henkelman M, Xie W, Jia Z (2011) p21Activated kinases 1 and 3 control brain size through coordinating neuro- 
nal complexity and synaptic properties. Mol Cell Biol 31:388-403. CrossRef Medline

Huang Y, Mucke L (2012) Alzheimer Mechanisms and Therapeutic Strategies. Cell 148:1204-1222. CrossRef Medline

Julien C, Tremblay C, Bendjelloul F, Phivilay A, Coulombe MA, Emond V, Calon F (2008) Decreased drebrin mRNA expression in Alzheimer disease: correlation with tau pathology. J Neurosci Res 86:2292-2302. CrossRef Medline

Julien C, Tremblay C, Emond V, Lebbadi M, Salem N Jr, Bennett DA, Calon F (2009) Sirtuin 1 reduction parallels the accumulation of tau in Alzheimer disease. J Neuropathol Exp Neurol 68:48-58. CrossRef Medline

Julien C, Tremblay C, Phivilay A, Berthiaume L, Emond V, Julien P, Calon F (2010) High-fat diet aggravates amyloid-beta and tau pathologies in the 3xTg-AD mouse model. Neurobiol Aging 31:1516-1531. CrossRef Medline

Kaidanovich-Beilin O, Lipina T, Vukobradovic I, Roder J, Woodgett J (2011) Assessment of social interaction behaviors. J Vis. Exp 48.

Kamenetz F, Tomita T, Hsieh H, Seabrook G, Borchelt D, Iwatsubo T, Sisodia S, Malinow R (2003) APP processing and synaptic function. Neuron 37:925-937. CrossRef Medline

Kang DE, Roh SE, Woo JA, Liu T, Bu JH, Jung AR, Lim Y (2011) The interface between cytoskeletal aberrations and mitochondrial dysfunction in Alzheimer's disease and related disorders. Exp Neurobiol 20:67-80. CrossRef Medline

Kingsbury AE, Foster OJ, Nisbet AP, Cairns N, Bray L, Eve DJ, Lees AJ, Marsden CD (1995) Tissue $\mathrm{pH}$ as an indicator of mRNA preservation in human post-mortem brain. Brain Res Mol Brain Res 28:311-318. CrossRef Medline

Kojima N, Shirao T (2007) Synaptic dysfunction and disruption of postsynaptic drebrin-actin complex: a study of neurological disorders accompanied by cognitive deficits. Neurosci Res 58:1-5. CrossRef Medline

Kojima N, Hanamura K, Yamazaki H, Ikeda T, Itohara S, Shirao T (2010) Genetic disruption of the alternative splicing of drebrin gene impairs context-dependent fear learning in adulthood. Neuroscience 165:138-150. CrossRef Medline

Kreis P, Barnier JV (2009) PAK signalling in neuronal physiology. Cell Signal 21:384-393. CrossRef Medline

Kwon CH, Luikart BW, Powell CM, Zhou J, Matheny SA, Zhang W, Li Y, Baker SJ, Parada LF (2006) Pten Regulates Neuronal Arborization and Social Interaction in Mice. Neuron 50:377-388. CrossRef Medline

Lacor PN, Buniel MC, Furlow PW, Clemente AS, Velasco PT, Wood M, Viola KL, Klein WL (2007) Abeta Oligomer-Induced Aberrations in Synapse Composition, Shape, and Density Provide a Molecular Basis for Loss of Connectivity in Alzheimer's Disease. J Neurosci 27:796-807. CrossRef Medline

Larson EB, Kukull WA, Katzman RL (1992) Cognitive Impairment: Dementia and Alzheimer's Disease. Annual Review of Public Health 13:431-449. CrossRef Medline

Ma QL, Yang F, Calon F, Ubeda OJ, Hansen JE, Weisbart RH, Beech W, Frautschy SA, Cole GM (2008) p21-activated kinase aberrant activation and translocation in Alzheimer's disease pathogenesis. J Biol Chem.

Martinez-Coria H, Green KN, Billings LM, Kitazawa M, Albrecht M, Rammes G, Parsons CG, Gupta S, Banerjee P, LaFerla FM (2010) Memantine improves cognition and reduces Alzheimer's-like neuropathology in transgenic mice. Am J Pathol 176:870-880. CrossRef Medline

Masliah E, Crews L, Hansen L (2006) Synaptic remodeling during aging and in Alzheimer's disease. J Alzheimers Dis 9:91-99. Medline

Mastrangelo MA, Bowers WJ (2008) Detailed immunohistochemical characterization of temporal and spatial progression of Alzheimer's diseaserelated pathologies in male triple-transgenic mice. BMC Neurosci 9:81. CrossRef Medline

Meng J, Meng Y, Hanna A, Janus C, Jia Z (2005) Abnormal Long-Lasting Synaptic Plasticity and Cognition in Mice Lacking the Mental Retardation Gene Pak3. J Neurosci 25:6641-6650. CrossRef Medline

Minamide LS, Striegl AM, Boyle JA, Meberg PJ, Bamburg JR (2000) Neurodegenerative stimuli induce persistent $\mathrm{ADF} /$ cofilin-actin rods that disrupt distal neurite function. Nat Cell Biol 2:628-636. CrossRef Medline

Moolman DL, Vitolo OV, Vonsattel JP, Shelanski ML (2004) Dendrite and dendritic spine alterations in Alzheimer models. J Neurocytol 33:377-387. CrossRef Medline

Morrow EM, Kane A, Goff DC, Walsh CA (2008) Sequence analysis of P21activated kinase 3 (PAK3) in chronic schizophrenia with cognitive impairment. Schizophrenia research 106:265-267. CrossRef Medline
Nekrasova T, Jobes ML, Ting JH, Wagner GC, Minden A (2008) Targeted disruption of the Pak5 and Pak6 genes in mice leads to deficits in learning and locomotion. Developmental Biology 322:95-108. CrossRef Medline

Nelson PT, Alafuzoff I, Bigio EH, Bouras C, Braak H, Cairns NJ, Castellani RJ, Crain BJ, Davies P, Del Tredici K, Duyckaerts C, Frosch MP, Haroutunian V, Hof PR, Hulette CM, Hyman BT, Iwatsubo T, Jellinger KA, Jicha GA, Kövari E, et al. (2012) Correlation of Alzheimer disease neuropathologic changes with cognitive status: a review of the literature. J Neuropathol Exp Neurol 71:362-381. CrossRef Medline

Nguyen TV, Galvan V, Huang W, Banwait S, Tang H, Zhang J, Bredesen DE (2008) Signal transduction in Alzheimer disease: $\mathrm{p} 21$-activated kinase signaling requires C-terminal cleavage of APP at Asp664. J Neurochem 104:1065-1080. CrossRef Medline

Nikolić M (2008) The Pak1 kinase: an important regulator of neuronal morphology and function in the developing forebrain. Molecular Neurobiology 37:187-202. CrossRef Medline

O'Brien RJ, Wong PC (2011) Amyloid precursor protein processing and Alzheimer's disease. Annu Rev Neurosci 34:185-204. CrossRef Medline

Oddo S, Caccamo A, Kitazawa M, Tseng BP, LaFerla FM (2003a) Amyloid deposition precedes tangle formation in a triple transgenic model of Alzheimer's disease. Neurobiol Aging 24:1063-1070. CrossRef Medline

Oddo S, Caccamo A, Shepherd JD, Murphy MP, Golde TE, Kayed R, Metherate R, Mattson MP, Akbari Y, LaFerla FM (2003b) Triple-Transgenic Model of Alzheimer's Disease with Plaques and Tangles: Intracellular A[beta] and Synaptic Dysfunction. Neuron 39:409-421. CrossRef Medline

Phivilay A, Julien C, Tremblay C, Berthiaume L, Julien P, Giguère Y, Calon F (2009) High dietary consumption of trans fatty acids decreases brain docosahexaenoic acid but does not alter amyloid-beta and tau pathologies in the 3xTg-AD model of Alzheimer's disease. Neuroscience 159:296-307. CrossRef Medline

Ramakers GJ (2002) Rho proteins, mental retardation and the cellular basis of cognition. Trends Neurosci 25:191-199. CrossRef Medline

Rodríguez JJ, Verkhratsky A (2011) Neurogenesis in Alzheimer's disease. J Anat 219:78-89. CrossRef Medline

Rousseau V, Goupille O, Morin N, Barnier JV (2003) A New Constitutively Active Brain PAK3 Isoform Displays Modified Specificities toward Rac and Cdc42 GTPases. J Biol Chem 278:3912-3920. CrossRef Medline

Salminen A, Suuronen T, Kaarniranta K (2008) ROCK, PAK, and Toll of synapses in Alzheimer's disease. Biochem Biophys Res Commun 371: 587-590. CrossRef Medline

Scheff SW, Price DA (2006) Alzheimer's disease-related alterations in synaptic density: neocortex and hippocampus. J Alzheimers Dis 9:101-115. Medline

Selkoe DJ (2011) Resolving controversies on the path to Alzheimer's therapeutics. Nat Med 17:1060-1065. CrossRef Medline

Selkoe DJ (2001) Alzheimer's disease: genes, proteins, and therapy. Physiol Rev 81:741-766. Medline

Shim KS, Lubec G (2002) Drebrin, a dendritic spine protein, is manifold decreased in brains of patients with Alzheimer's disease and Down syndrome. Neurosci Lett 324:209-212. CrossRef Medline

Silverman JL, Yang M, Lord C, Crawley JN (2010) Behavioural phenotyping assays for mouse models of autism. Nat Rev Neurosci 11:490-502. CrossRef Medline

Steinerman JR, Irizarry M, Scarmeas N, Raju S, Brandt J, Albert M, Blacker D, Hyman B, Stern Y (2008) Distinct pools of beta-amyloid in Alzheimer disease-affected brain: a clinicopathologic study. Arch Neurol 65:906-912. CrossRef Medline

Sterniczuk R, Antle MC, Laferla FM, Dyck RH (2010) Characterization of the 3xTg-AD mouse model of Alzheimer's disease: part 2. Behavioral and cognitive changes. Brain Res 1348:149-155. CrossRef Medline

Szczepanowska J (2009) Involvement of Rac/Cdc42/PAK pathway in cytoskeletal rearrangements. Acta Biochim Pol.

Tremblay C, Pilote M, Phivilay A, Emond V, Bennett DA, Calon F (2007) Biochemical characterization of Abeta and tau pathologies in mild cognitive impairment and Alzheimer's disease. J Alzheimers Dis 12: 377-390. Medline

VanGuilder HD, Farley JA, Yan H, Van Kirk CA, Mitschelen M, Sonntag WE, Freeman WM (2012) Hippocampal dysregulation of synaptic plasticityassociated proteins with age-related cognitive decline. Neurobiol Dis 43: 201-212. CrossRef Medline

Verret L, Mann EO, Hang GB, Barth AM, Cobos I, Ho K, Devidze N, Masliah E, Kreitzer AC, Mody I, Mucke L, Palop JJ (2012) Inhibitory Interneu- 
ron Deficit Links Altered Network Activity and Cognitive Dysfunction in Alzheimer Model. Cell 149:708-721. CrossRef Medline

Wilson RS, Beckett LA, Barnes LL, Schneider JA, Bach J, Evans DA, Bennett DA (2002) Individual differences in rates of change in cognitive abilities of older persons. Psychol Aging 17:179-193. CrossRef Medline

Winslow JT (2001) Mouse social recognition and preference. In: Current protocols in neuroscience. New York: Wiley.

Zenke FT, King CC, Bohl BP, Bokoch GM (1999) Identification of a central phosphorylation site in p21-activated kinase regulating autoinhibition and kinase activity. J Biol Chem 274:32565-32573. CrossRef Medline

Zhang ZW, Arsenault D (2005) Gain modulation by serotonin in pyramidal neurones of the rat prefrontal cortex. J Physiol 566:379-394. CrossRef Medline

Zhao L, Ma QL, Calon F, Harris-White ME, Yang F, Lim GP, Morihara T, Ubeda OJ, Ambegaokar S, Hansen JE, Weisbart RH, Teter B, Frautschy SA, Cole GM (2006) Role of p21-activated kinase pathway defects in the cognitive deficits of Alzheimer disease. Nat Neurosci 9:234-242. CrossRef Medline

Zhao Z-S, Manser E, Chen XQ, Chong C, Leung T, Lim L (1998) A conserved negative regulatory region in alphaPAK: inhibition of PAK kinases reveals their morphological roles downstream of Cdc42 and Racl. Mol Cell Biol 18:2153-2163. Medline 